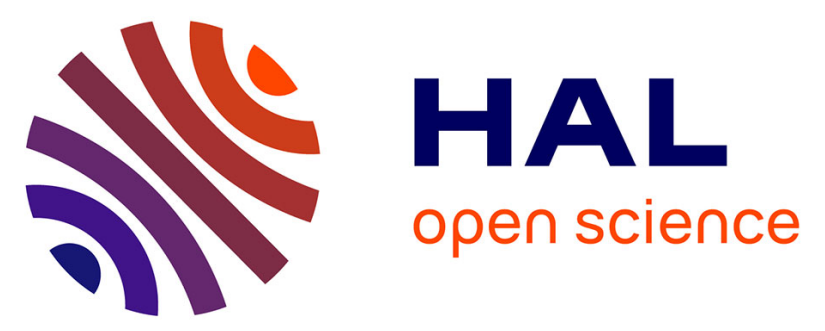

\title{
Centennial to millennial-scale changes in oxygenation and productivity in the Eastern Tropical South Pacific during the last 25,000 years
}

Renato Salvatteci, Dimitri Gutiérrez, Abdelfettah Sifeddine, Luc Ortlieb, E. Druffel, Mohammed Boussafir, R. Schneider

\section{To cite this version:}

Renato Salvatteci, Dimitri Gutiérrez, Abdelfettah Sifeddine, Luc Ortlieb, E. Druffel, et al.. Centennial to millennial-scale changes in oxygenation and productivity in the Eastern Tropical South Pacific during the last 25,000 years. Quaternary Science Reviews, 2016, 131 (Part A), pp.102-117. 10.1016/j.quascirev.2015.10.044 . hal-01235970

\section{HAL Id: hal-01235970 https://hal.sorbonne-universite.fr/hal-01235970}

Submitted on 1 Dec 2015

HAL is a multi-disciplinary open access archive for the deposit and dissemination of scientific research documents, whether they are published or not. The documents may come from teaching and research institutions in France or abroad, or from public or private research centers.
L'archive ouverte pluridisciplinaire HAL, est destinée au dépôt et à la diffusion de documents scientifiques de niveau recherche, publiés ou non, émanant des établissements d'enseignement et de recherche français ou étrangers, des laboratoires publics ou privés. 
1 Centennial to millennial-scale changes in oxygenation and productivity in the Eastern

2 Tropical South Pacific during the last 25000 years

3

$4 \quad$ R. Salvatteci ${ }^{1,2^{*}}$; D. Gutierrez ${ }^{3,4}$; A. Sifeddine ${ }^{1,5}$; L. Ortlieb ${ }^{1}$, E. Druffel ${ }^{6} ;$ M. Boussafir ${ }^{7}$; R.

5 Schneider $^{2}$

$6{ }^{1}$ IRD-Sorbonne Universités (UPMC, Univ. Paris 06)-CNRS-MNHN, LOCEAN Laboratory,

7 Center IRD France-Nord, 32, Avenue Henri Varagnat, F-93143 Bondy, France

$8{ }^{2}$ Institute of Geoscience, Department of Geology, Kiel University, Ludewig-Meyn-Str. 10,

924118 Kiel, Germany

$10{ }^{3}$ Instituto del Mar del Perú, Esquina Gamarra y General Valle s/n, Callao 22000, Peru

$11{ }^{4}$ Programa Maestría en Ciencias del Mar, Universidad Peruana Cayetano Heredia, Lima, 12 Peru

$13{ }^{5}$ Departamento de Geoquimica, Universidade Federal Fluminense, Niteroi, Brazil

$14{ }^{6}$ Department of Earth System Science, University of California - Irvine, California, USA

$15{ }^{7}$ Institut des Sciences de la Terre d'Orléans, UMR7327 - INSU/CNRS/BRGM/Université

16 d'Orléans, 1A rue de la férollerie, 45701 Orléans CEDEX-2, France

$17 *$ Corresponding author. E-mail address: renatosalvatteci@ gmail.com

19 Keywords: redox sensitive metals, denitrification, oxygen minimum zone, Peruvian 20 upwelling ecosystem, paleoceanography. 


\section{ABSTRACT}

Oxygen minimum zones (OMZ) have expanded in all tropical oceans during the last 50 years resulting in habitat contraction and considerable changes in marine biogeochemistry. However, for a better understanding of the $\mathrm{OMZ}$ dynamics under the current climate change, two questions are relevant: 1) how do the magnitude and temporal changes in oceanic dissolved oxygen of the last few decades compare to the natural variability on longer timescales, and 2) what were the local and remote factors driving OMZ changes in the past. In the present study we use a stacked record covering the last $25 \mathrm{kyr}$ from the Eastern Tropical South Pacific (ETSP) OMZ to reconstruct changes in oxygenation and productivity. We use a suite of proxies including the presence of laminations, redox sensitive metals (U, $\mathrm{Mo}, \mathrm{Re}, \mathrm{Ni}$ and $\mathrm{Cu}$ ), total organic carbon and $\delta^{15} \mathrm{~N}$ measurements. Water column denitrification and sediment redox conditions show pronounced centennial to millennial-scale variability during the last $25 \mathrm{kyr}$, with oxygenation levels as low as at present. Global cold periods at different timescales such as the Last Glacial Maximum (23 to $19 \mathrm{kyr}$ BP) and the Little Ice Age (1500 to $1850 \mathrm{AD}$ ) were associated with a weak OMZ and low export production, while warm intervals such as the deglaciation, part of the Medieval Climate Anomaly and the last 100 years are associated with a stronger OMZ and high export production. Water column denitrification and sediment redox conditions were strongly coupled during the last $25 \mathrm{kyr}$ BP apart from one remarkable exception: during the Antarctic Cold Reversal, sediments were less reducing but the water column denitrification was high resulting in a strong but shallow OMZ. This may have been produced by an enhanced Antarctic Intermediate Water flow. Contrary to our expectations and modeling predictions for the next few decades, we observe a weak ETSP-OMZ during the warm mid-Holocene, which may have been the result of a stronger Walker Circulation that brought oxygen-rich waters to intermediate depths off Peru via Equatorial undercurrents. In combination with other paleoceanographic reconstructions, our results show that oxygenation variability in the ETSP-OMZ was influenced by ocean circulation changes in the Tropical Pacific, high latitude oceanographic and climatic changes, and local productivity. 


\section{INTRODUCTION}

Oxygen concentration in the ocean affects marine biogeochemical processes and the behavior and distribution of marine biota (Stramma et al., 2008; 2010b; Gilly et al., 2013). In the Eastern Tropical Pacific, a strong and shallow oxygen minimum zone (OMZ) is maintained at intermediate depths as a result of weak ocean ventilation and the decay of organic matter as a result of intense biological production (Pennington et al., 2006; Karstensen et al., 2008). The low oxygen concentration modifies microbial processes and the cycles of the macronutrients nitrogen and phosphorus. Although OMZ waters constitute only $\sim 0.1 \%$ of the ocean volume, up to $40 \%$ of the total loss of the ocean's bioavailable nitrogen, a macronutrient limiting primary productivity, occurs in these zones (Kuypers et al., 2005; Lam et al., 2009). During the last 50 years, OMZs have expanded both horizontally and vertically in all tropical oceans, likely due to anthropogenic impacts (Stramma et al., 2008; 2010). Global warming is expected to further reduce the oxygen supply to the oceans, producing a continuous expansion of the OMZs and resulting in habitat contraction and considerable changes in marine biogeochemistry (Gilly et al., 2013). However, it is still an open question as to how the magnitude and temporal changes in oceanic dissolved oxygen of the last few decades compare to the natural variability on longer timescales. Moreover, it is not clear how the OMZ in the Eastern Tropical South Pacific (ETSP) responded to prior episodes of climate changes, and the local and remote driving factors remain unknown. In the present work, we reconstruct changes in oceanic oxygenation and export production for the last 25000 years before present (kyr BP), using sediment cores retrieved from the ETSP-OMZ. We then compare our records with other paleoceanographic reconstructions to identify local and remote driving factors for changes in $\mathrm{OMZ}$ intensity.

Reconstructions of past oxygenation in the sediments are based on the use of proxies that record the redox state at the sediment-water interface, such as laminations, redoxsensitive trace metals, and foraminiferal species assemblages (Jaccard et al., 2014). These proxies are likely to detect either changes in the magnitude and distribution of biological export production and/or modifications in ventilation through bottom currents. The presence of laminae provides strong evidence for low oxygen concentrations $\left(<7 \mu \mathrm{mol} \mathrm{kg}{ }^{-1}\right.$, Schönfeld et al., 2015), as low oxygen contents and high sedimentation rates impede sediment reworking by benthic organisms. By contrast, the absence of laminae is not necessarily a proof of oxygenation, but is more likely related to a complex interplay of factors including 
turbidite flows, slumps, winnowing by strong currents, bioturbation, and a lack of regular variation in terrigenous and biological material (Salvatteci et al., 2014a). Benthic redox conditions are generally recognized to have a dominant influence on the accumulation of authigenic trace metals (e.g., molybdenum, rhenium, and uranium) in marine sediments (Algeo and Tribovillard, 2009). The solubility of redox-sensitive metals decreases under reducing conditions. Reducing conditions commonly occur within the upper centimeters of the sediments, thus the presence or absence of these elements in sedimentary deposits is used to infer past reducing conditions (McManus et al., 2006). Benthic foraminifer assemblages are indicative of past changes in oxygen under certain conditions, but sediments from the Peruvian margin show extensive periods of benthic and planktonic foraminifera dissolution, limiting the use of this proxy to reconstruct high resolution changes in past oxygen concentration (Rein et al., 2005). Consequently, the most reliable approach to infer past oxygenation changes is the combined use of several proxies (Hendy and Pedersen, 2006; Nameroff et al., 2004; Algeo and Tribovillard, 2009; Helz and Adelson, 2013; Jaccard et al., 2014; Scholz et al., 2014; Little et al., 2015).

Water column denitrification has also been indirectly inferred through the use of $\delta^{15} \mathrm{~N}$ in sedimentary organic matter (Higginson and Altabet, 2004; Chazen et al., 2009; Scholz et al., 2014). In oxygen-deficient waters $\left(<2-10 \mu \mathrm{mol} \mathrm{O}_{2} \mathrm{~L}^{-1}\right)$, N-loss processes, such as denitrification $\left(\mathrm{NO}_{3}^{-} \rightarrow \mathrm{N}_{2}\right.$ via $\mathrm{NO}_{2}^{-}$) and anammox (anaerobic ammonia oxidation; $\mathrm{NO}_{2}^{-} \rightarrow$ $\mathrm{NH}_{4}^{+} \rightarrow \mathrm{N}_{2}$; Lam et al., 2009) take place. Under these conditions, $\mathrm{NO}_{3}$ is used as an oxidant during organic matter degradation resulting in isotopically light $\mathrm{N}_{2}$ and $\mathrm{N}_{2} \mathrm{O}$ and isotopically heavier residual $\mathrm{NO}_{3}$. This heavy $\mathrm{NO}_{3}$ is upwelled to the surface, used by phytoplankton, and eventually deposited into the sediments. Thus, in sites where high sedimentation rates and low oxygen concentrations prevail, a bulk sediment $\delta^{15} \mathrm{~N}$ analysis can be used to reconstruct past changes in N-loss (Higginson and Altabet, 2004; Mollier-Vogel et al., 2012). Although the relative importance of denitrification and anammox is strongly debated for the Peruvian OMZ, both of them are denitrification reactions driven by an intense OMZ (Lam et al., 2009; Zehr, 2009). However, other processes that are not influenced by oxygen concentrations contribute to the $\delta^{15} \mathrm{~N}$ signal, most importantly the partial $\mathrm{NO}_{3}$ utilization by phytoplankton (Mollier-Vogel et al., 2012; Ehlert et al., 2015). During photosynthesis, phytoplankton preferentially take up $\mathrm{NO}_{3}$ containing the lighter isotope; therefore, the produced organic matter is depleted in ${ }^{15} \mathrm{~N}$ relative to the upwelled $\mathrm{NO}_{3}$. A low relative $\mathrm{NO}_{3}$ utilization results 
123 in lower particulate organic matter $\delta^{15} \mathrm{~N}$ values compared to upwelled $\mathrm{NO}_{3} \delta^{15} \mathrm{~N}$ values, independent from oxygen conditions in the water column (Waser et al., 1998). Currently, off central and northern Peru, water column measurements show that $\mathrm{NO}_{3}$ and $\mathrm{PO}_{4}$ concentrations do not limit phytoplankton growth, thus partial $\mathrm{NO}_{3}$ utilization occurs (Moore et al., 2013). It is therefore likely that $\delta^{15} \mathrm{~N}$ in bulk sediments in this region reflects both water-column $\mathrm{N}$-loss increasing the $\delta^{15} \mathrm{~N}$ of upwelled $\mathrm{NO}_{3}$ (indicating low-oxygen conditions), and, subsequent partial utilization causing $\delta^{15} \mathrm{~N}$ in the organic matter to be lower than upwelled $\mathrm{NO}_{3} \delta^{15} \mathrm{~N}$ (Mollier-Vogel et al., 2012; Ehlert et al., 2015). Although we are aware of the different processes controlling $\delta^{15} \mathrm{~N}$ values in sediments, we will, for simplicity, use the term "denitrification" as a proxy for water column oxygenation.

Paleoceanographic reconstructions indicate that the ETSP-OMZ water column denitrification and sediment redox conditions vary strongly at multi-decadal and centennial (Gutierrez et al., 2009; Salvatteci et al., 2014b), millennial (Higginson and Altabet, 2004; Chazen et al., 2009), and glacial-interglacial timescales (Scholz et al., 2014), in response to climate fluctuations however, the underlying mechanisms are still unclear. Global cold periods such as the Last Glacial Maximum (LGM; 23 to $19 \mathrm{kyr}$ BP) and the Little Ice Age (LIA; 1500 to $1850 \mathrm{AD}$ ) were generally associated with an OMZ contraction, while warm intervals such as the deglaciation ( 17 to $13 \mathrm{kyr}$ BP), part of the Medieval Climate Anomaly (MCA; 900 to $1350 \mathrm{AD}$ ) and the last 100 years were associated with an OMZ expansion (Higginson and Altabet, 2004; Gutierrez et al., 2009; Salvatteci et al., 2014b). Oxygen reconstructions for the last 2 millennia, both in the water column and the sediments, have been done at multidecadal sampling (Gutierrez et al., 2009; Salvatteci et al., 2014b). This approach can be used to reconstruct changes in ventilation below the OMZ by assessing the coupling/decoupling of oxygenation in the water column and sediments. Several mechanisms have been proposed to explain the observed oxygenation variability. The reduced denitrification (i.e. OMZ weakening) during glacial stages, for example, is attributed to decreased export production and lower oxygen demand, in addition to increased oxygen solubility due to lower surface temperature (Galbraith et al., 2004). Nevertheless, reconstructing changes in oxygen remains complicated due to the above-mentioned restrictions of the different proxies. Moreover, the multiple discontinuities and limitations in the accuracy of ${ }^{14} \mathrm{C}$ measurements in the sediments from the Peruvian margin, prevent the establishment of robust age models. Thus, this prevents comparison with other well-dated 
records. For these reasons, the understanding of the main processes controlling oxygenation changes remains unresolved.

The present study is based on a stacked record covering the last $25 \mathrm{kyr}$ to reconstruct changes in oxygenation and productivity using a suite of proxies including the presence of laminations, redox sensitive metals and $\delta^{15} \mathrm{~N}$. Moreover, we carefully examined the sediment records with X-ray images, to identify laminated, banded, slumped, and mixed sediment sequences to develop a strong and reliable age model constructed with $60{ }^{14} \mathrm{C}$ calibrated ages taken only from laminated sequences to avoid age inversions. The past $25 \mathrm{kyr}$ comprise periods of global ocean circulation and climate changes. The comparison of contrasting climate and ocean circulation conditions provides insight into the underlying mechanisms producing changes in productivity and OMZ intensity. The objectives of the present study are: 1) to reconstruct centennial to millennial scale changes in oxygenation and productivity, 2) to assess the coupling-decoupling between water column and sediment redox conditions, and 3) to unravel the main processes controlling oxygenation changes in the ETSP by comparing our record with other relevant records from the literature. A sound understanding of these processes is fundamental for projecting potential future scenarios of the ETSP-OMZ.

\section{OCEANOGRAPHIC CONTEXT OF STUDY SITE}

The Peruvian upwelling ecosystem (PUE) is an eastern boundary system characterized by a shallow surface mixed layer and high productivity driven by the upwelling of cold, nutrientrich and oxygen-poor waters from intermediate depths (Fig. 1A and B; Pennington et al., 2006). The intense upwelling of waters rich in nitrate, phosphate, silicic acid and iron to surface waters induces massive phytoplankton blooms, which at times extend over the shelf offshore (Bruland et al., 2005). The main source of the upwelled water is the nutrient-rich poleward undercurrent (PUC) located between 50 and 400 meters depth, which is in contact with shelf sediments (Bruland et al., 2005; Karstensen and Ulloa, 2009). Approximately 30\% of the PUC originates from the primary and secondary Southern Subsurface Countercurrents (SSCCs) and to a considerably lesser degree, from the Equatorial Undercurrent (EUC). The remaining $70 \%$ of the PUC is composed of alongshore recirculation associated with flows below it and of weak diffuse currents south of $\sim 9{ }^{\circ} \mathrm{S}$ (Montes et al., 2010). Changes in the intensity, ventilation, and nutrient concentrations of water in these countercurrents affect the 
oxygen content and nutrient availability in the subsurface waters off Peru, which eventually fuel the euphotic layers.

The ETSP-OMZ is defined by an oxygen saturation level of $<\sim 10 \%$ of that at the sea surface (Gilly et al., 2013), which corresponds to an oxygen concentration of $<20 \mu \mathrm{mol} \mathrm{kg}{ }^{-1}$ $\left(0.5 \mathrm{ml} \mathrm{L}^{-1}\right.$; Helly and Levi, 2004; Fuenzalida et al., 2009). On average, the ETSP-OMZ ranges from $\sim 50$ to 500 meters depth, and is thickest off Peru between $5^{\circ}$ and $13^{\circ} \mathrm{S}$ (Fig. 1B; Fuenzalida et al., 2009). The upper boundary is shallowest off Peru, shoaling towards the coast and in some cases overlapping the euphotic zone (Fuenzalida et al., 2009). However it varies on seasonal and interannual timescales, allowing for the intrusion of benthic fauna from the upper slope that recurrently causes sediment mixing (Gutierrez et al., 2008). During the strong El Niño event of 1997-98, the upper OMZ boundary deepened to $190 \mathrm{~m}$ causing a mild oxygenation of an otherwise anoxic upper slope (200-300m) allowing the presence of benthic fauna (Sanchez et al., 2000; Levin et al., 2002). The ETSP-OMZ is supplied with oxygen-rich water from zonal tropical currents: near the equator, EUC, the SSCCs and the Southern Intermediate Countercurrents (SICC; Furue et al., 2007). These currents provide a net oxygen supply to the ETSP-OMZ (Stramma et al., 2010a).

\section{MARINE GEOCHEMICAL BEHAVIOR OF TRACE METALS}

Reconstructions of paleo-redox conditions are usually based on several redoxsensitive metals. However, one of the difficulties in using these elements as proxies for past geochemical conditions is that sedimentary reducing conditions may be controlled by two complementary processes: low dissolved oxygen availability above the sediments and the delivery of reactive organic carbon to the seafloor (McManus et al., 2006). The concentrations of redox-sensitive metals in sediment records have been used to discern paleoredox conditions, with higher trace metal enrichments suggesting more reducing conditions (Tribovillard et al., 2006; Morford et al., 2012). Redox classification of the depositional environments can be subdivided into oxic $\left(>2.0 \mathrm{~m} \mathrm{O}_{2} \mathrm{~L}^{-1}\right)$, dysoxic or suboxic $\left(\sim 0.2-2 \mathrm{ml} \mathrm{O}_{2} \mathrm{~L}^{-1}\right)$, anoxic non-sulfidic $\left(<0.2 \mathrm{ml} \mathrm{O}_{2} \mathrm{~L}^{-1}, 0 \mathrm{ml} \mathrm{H}_{2} \mathrm{~S} \mathrm{~L}^{-1}\right)$, and anoxic-sulfidic or euxinic $\left(0 \mathrm{ml} \mathrm{O}_{2} \mathrm{~L}^{-1}\right.$, >0 $\left.\mathrm{ml} \mathrm{H}_{2} \mathrm{~S} \mathrm{~L}^{-1}\right)$ conditions (Savrda and Bottjer, 1991; Tribovillard et al., 2006; Algeo and Tribovillard, 2009). The sum of the measured metal concentrations contains a detrital background and an authigenic fraction (i.e. the part in excess of the detrital background; Tribovillard et al., 2006). The authigenic (or non-lithogenic) fraction is mainly 
enriched by syn- or post-depositional redox reactions, and each element exhibits different sensitivities to the redox conditions along the oxic to sulfidic gradient. As in some cases, trace elements present a strong detrital fraction, thus we focus on the authigenic trace element content.

\subsection{Molybdenum}

In modern seawater, molybdenum (Mo) is present as the stable and largely unreactive molybdate oxyanion $\left(\mathrm{MoO}_{4}^{2-} / \mathrm{Mo}(\mathrm{VI})\right)$, with a seawater concentration of $\sim 104 \mathrm{nmol} \mathrm{kg-1,} \mathrm{a}$ residence time of $8.7 \times 10^{5} \mathrm{yr}$, and a conservative behavior (Colodner et al., 1993; Algeo and Tribovillard, 2009; Miller et al., 2011). The uptake mechanisms of authigenic Mo $\left(\mathrm{Mo}_{\text {auth }}\right)$ by sediments are well understood (Morford et al., 2005; Algeo and Tribovillard, 2009). $\mathrm{Mo}_{\text {auth }}$ enrichment is limited in oxic environments, whereas under anoxic-sulfidic conditions (i.e. above a hydrogen sulfide concentration of $\sim 50-250 \mu \mathrm{M} \mathrm{HS}^{-}$), Mo becomes activated facilitating the conversion of molybdate to thiomolybdates $\left(\mathrm{MoO}_{\mathrm{x}} \mathrm{S}_{4-\mathrm{x}}^{2-}, \mathrm{x}=0\right.$ to 3 ) (Helz et al., 1996; Zheng et al., 2000; Algeo and Tribovillard, 2009). During shallow diagenesis, considerable amounts of Mo sorb onto and become incorporated into pyrite, an authigenic mineral that can endure oxidation during sediment burial (Sundby et al., 2004; Helz and Adelson, 2013). There are three main factors influencing the $\mathrm{Mo}_{\text {auth }}$ uptake by sediments: 1) benthic redox conditions including the mean redox state and the degree of redox variability, 2) the operation of a particulate shuttle linked to Mn-Fe redox cycling, scavenging Mo from the water column, thereby raising its concentration near the sediment surface and speeding its diffusion into sediments, and 3) changes in the chemistry of the overlying water column (Algeo and Tribovillard, 2009; Scholz et al., 2013; Helz and Adelson, 2013). The behavior of Mo in sediments strongly suggests that Mo is a reliable proxy for benthic redox conditions at localities with, at minimum, sporadically sulfidic conditions (Scholz et al., 2011; Helz and Adelson, 2013).

\subsection{Uranium}

In modern seawater, uranium (U) is present as the chemically unreactive uranyl carbonate $\left(\mathrm{UO}_{2}\left(\mathrm{CO}_{3}\right)_{3}^{4-}, \mathrm{U}(\mathrm{VI})\right)$, with a seawater concentration of $\sim 13 \mathrm{nmol} \mathrm{kg-1}$, a residence time of $4.5 \times 10^{5} \mathrm{yr}$, and conservative behavior (McManus et al., 2006; Algeo and Tribovillard, 2009; Miller et al., 2011). In oxic environments, U enrichment is limited, whereas under anoxic conditions $U$ (VI) is reduced to U (IV) forming either the highly 
soluble uranyl ion $\mathrm{UO}_{2}^{+}$or the less soluble uranous fluoride complexes (Algeo and Tribovillard, 2009). This reduction occurs in the sediments suggesting that the reduction process may take place on particle surfaces, possibly catalyzed by enzymes produced by iron and sulfate-reducing bacteria (Algeo and Tribovillard, 2009; Morford et al., 2009; Scholz et al., 2011). The uptake of $U_{\text {auth }}$ by sediments may occur through the formation of organicmetal ligands in humic acids or by precipitation of crystalline uraninite $\left(\mathrm{UO}_{2}\right)$ or it's precursor (Zheng et al., 2002; Algeo and Tribovillard 2009). The reduction of U starts at the $\mathrm{Fe}(\mathrm{II})-\mathrm{Fe}$ (III) redox boundary and is likely controlled by microbially -mediated Fe reduction rather than by the presence of $\mathrm{HS}^{-}$(Zheng et al., 2002; Algeo and Tribovillard, 2009). This indicates that the onset of $U_{\text {auth }}$ enrichment occurs under less reducing conditions compared to Mo and at shallower depths (Morford et al., 2009; Algeo and Tribovillard, 2009). In the water column, $\mathrm{U}$ is not influenced by the $\mathrm{Mn}-\mathrm{Fe}$ redox cycling, therefore, most of the $\mathrm{U}_{\text {auth }}$ in anoxic sediments is delivered by diffusion across the sediment-bottom water interface (McManus et al., 2006; Algeo and Tribovillard, 2009; Scholz et al., 2011).

\subsection{Rhenium}

In modern seawater, rhenium $(\mathrm{Re})$ is present as the oxyanion perrhenate $\left(\mathrm{ReO}_{4}^{-}\right)(\mathrm{VII})$, with a seawater concentration of $\sim 40 \mathrm{pmol} \mathrm{kg}^{-1}$, a residence time of $7.2 \times 10^{5} \mathrm{yr}$, and conservative behavior (Colodner et al., 1993; Algeo and Tribovillard, 2009; Miller et al., 2011; Helz and Adelson, 2013). Whereas Re does not accumulate in oxic sediments, it can be highly enriched in anoxic and suboxic sediments, with concentrations exceeding the crustal average by 100 to 1000 times (i.e. 0.2 to 2 ng.g ${ }^{-1}$; Colodner et al., 1993; Böning et al., 2004; Helz and Dolor, 2012; Helz and Adelson, 2013). This characteristic renders Re a promising proxy to record redox conditions in the sediments, although it has hitherto received little attention in this context (Crusius et al., 1996; Nameroff et al., 2004; Böning et al., 2004; Helz and Adelson, 2013). The enrichment process involves the reduction of $\mathrm{ReO}_{4}^{-}$to an insoluble Re(IV) oxide or sulfide in suboxic and anoxic environments (Helz and Dolor, 2012). In contrast to Mo, Re is not adsorbed by Mn oxides and Fe oxyhydroxides surfaces in the water column (Morford et al., 2005; Helz and Adelson, 2013). During shallow diagenesis, Re tends to associate with organic matter, and during organic matter decomposition Re can be remobilized (Colodner et al., 1992; Helz et al., 2012; Helz and Adelson, 2013).

\subsection{Nickel}


In oxic marine environments, nickel (Ni) behaves as a micronutrient with a nutrientlike oceanic distribution. It is mostly present as a soluble $\mathrm{Ni}$ carbonate $\left(\mathrm{NiCO}_{3}\right)$ (II) or adsorbed to humic and fulvic acids, and is present in high amounts in plankton and sinking particles (Böning et al., 2004; Tribovillard et al., 2006). The main removal mechanism of Ni to reducing sediments seems to be settling with organic matter; $\mathrm{Ni}$ is brought to sediments from the ETSP-OMZ pre-concentrated on biodetritus settling through the water column (Tribovillard et al., 2006; Böning et al., 2004; 2015). During organic matter diagenesis Ni is released from organometallic complexes to pore waters. In moderately reducing sediments, $\mathrm{Ni}$ is released from the sediments to the overlying waters, whereas under (sulfate-) reducing conditions, $\mathrm{Ni}$ is likely to be incorporated as the insoluble NiS into pyrite (Böning et al., 2004; Dean et al., 2006; Tribovillard et al., 2006; Little et al., 2015).

\subsection{Copper}

In oxic seawater, copper $(\mathrm{Cu})$ is present as an organometallic ligand, and its concentration increases approximately linearly with depth, with a profile that is intermediate between scavenged and nutrient-like (Tribovillard et al., 2006; Little et al., 2015). Copper exhibits a complex geochemical behavior (Little et al., 2015), where it is both bioessential, and toxic to all photosynthesizing microorganisms at $\mathrm{Cu}^{2+}$ ion concentrations $>10^{-13} \mathrm{M}$ (Little et al., 2015). $\mathrm{Cu}$ is also present in high amounts in plankton and sinking particles (Böning et al., 2004). The main removal mechanism of $\mathrm{Cu}$ to reducing sediments is settling with organic matter, this metal is brought to sediments from the ETSP-OMZ pre-concentrated on biodetritus settling through the water column (Tribovillard et al., 2006; Böning et al., 2004; 2015). Copper complexation with organic matter as well as adsorption to particulate Fe-Mn oxyhydroxides, accelerates scavenging and thus sediment enrichment (Trivobillard et al., 2006; Böning et al., 2015; Little et al., 2015). During organic matter diagenesis or reductive dissolution of $\mathrm{Fe}-\mathrm{Mn}$-oxyhydroxides, $\mathrm{Cu}$ is released to pore waters. Under reducing conditions, $\mathrm{Cu}$ is likely to be incorporated into pyrite or may form its own sulfide phase (CuS and $\mathrm{CuS}_{2}$; Tribovillard et al., 2006). Nickel and $\mathrm{Cu}$ have high concentrations in the lithogenic fraction of sediments in contrast to Mo, $\mathrm{U}$ and Re, resulting in relatively low EF values (Böning et al., 2004; 2015). Thus, time periods associated with low $\mathrm{Ni}$ and $\mathrm{Cu}$ EFs could also be the result of processes not related to biogenic flux, such as fluctuations in the lithogenic sediment source and fluctuations in mineralogy.

\section{MATERIAL AND METHODS}




\subsection{Stacked record, age model and subsampling}

We reconstructed changes in productivity, sediment oxygenation, and water column denitrification over the last $25 \mathrm{kyr}$ at unprecedented resolution levels using a stacked record from three sediment cores retrieved at $14^{\circ} \mathrm{S}$ (Fig. 1). The stacked record is composed of cores G14 (390 m depth; $\left.14.38^{\circ} \mathrm{S}, 76.42^{\circ} \mathrm{W}\right)$, G10 (312 $\mathrm{m}$ depth; $\left.14.23^{\circ} \mathrm{S}, 76.4^{\circ} \mathrm{W}\right)$ and B14 (301 $\mathrm{m}$ depth; $\left.14.27^{\circ} \mathrm{S}, 76.43^{\circ} \mathrm{W}\right)$. Cores $\mathrm{G} 10$ and G14 were retrieved during the Galathea-3 expedition in 2007 and core B14 was taken during the Paleo-3 cruise in 2005 (Salvatteci et al., 2012; 2014a).

The complicated stratigraphy of sediment cores from the Peruvian margin strongly suggests the need for a detailed identification of the sediment structures using X-ray images prior to sub-sampling (Salvatteci et al., 2014a). This approach guarantees that the analyzed sediments are a result of deposition from the water column and not from reworking of upslope deposits. The identification of laminated, slumped, and homogeneous sequences must be done with X-ray images because these structures cannot be correctly identified with conventional photographic images or a visual description of the cores (see supp. mat.). Moreover, the dating of the sediment samples in laminated/banded sequences is essential to avoid age inversions. respectively, and are based on cumulative mass-depth due to large downcore changes in sediment density. Given the complicated sedimentological patterns of cores retrieved from the Peruvian shelf (Salvatteci et al., 2014a), we first carried out a detailed stratigraphic analysis based on careful examinations of X-ray images to identify laminated, banded, slumped, bioturbated, and winnowed sections (see supp. mat.). The ${ }^{14} \mathrm{C}$ analyses and all proxies were only developed on the laminated and banded sections of the core, because slumped sections cannot be accurately dated and their mixed sediments may result in erroneous paleoceanographic interpretations (Salvatteci et al., 2014a). Core G10 covers the Holocene from 10.3 to $0.4 \mathrm{kyr} \mathrm{BP}$, and G14 covers the glacial-interglacial transition from 25.2 to $13.4 \mathrm{kyr}$ BP. Sediment corresponding to the last $13.4 \mathrm{kyr}$ were not present in core G14, likely as a consequence of sub-marine landslides, which are common in this area. Sedimentation rates ranged from $0.3 \mathrm{~mm} \cdot \mathrm{y}^{-1}$ to $0.7 \mathrm{~mm} \cdot \mathrm{y}^{-1}$ for sediment samples corresponding to the LGM and to the Late Holocene respectively. The high sedimentation 
rates in the stacked record allows for high-resolution reconstructions. A detailed description of the age model is shown in the supplementary material. The age model for the last 2 millennia, showing the overlap between cores B14 and G10, is shown in Salvatteci et al. (2014b). Data for core B14 used in the stacked record was taken from Salvatteci et al. (2014b). The strong age model developed in the stacked record allows for the comparison with other high-resolution records.

Sub-sampling for trace elements and $\delta^{15} \mathrm{~N}$ was done following the stratigraphy of the stacked record avoiding the slumped sections. Laminated, banded and some homogeneous sequences were subsampled every $1 \mathrm{~cm}$ for trace elements and every $2 \mathrm{~cm}$ for $\delta^{15} \mathrm{~N}$ analyses. This sub-sampling strategy resulted in 363 trace element analyses and $268 \delta^{15} \mathrm{~N}$ measurements. Uranium was not measured in core B14. A detailed description of the subsampling of cores G10 and G14 is provided in the supplementary material. The subsampling criteria for B14 are described in Salvatteci et al. (2012; 2014b).

\subsection{Sediment structures as a record of benthic oxygenation}

Sediment cores retrieved from the core of the ETSP-OMZ often show homogeneous sequences between laminae packages. They have been suggested to be the result of bioturbation, (Brodie and Kemp, 1994), but a careful examination of multiple cores revealed that most of these sequences resulted from instantaneous downslope depositions (Salvatteci et al., 2014a). Therefore, in the present work we rely only on the laminated and banded sequences as a proxy for low oxygen concentration. In order to identify the mechanisms producing sediment homogenization, a detailed comparison with nearby cores would be required, however this would go beyond the scope of the present study.

In order to examine the sediment structures, digital X-ray images (i.e. SCOPIX) were obtained (Migeon et al., 1990) at the EPOC (Environnements et Paléoenvironnements Océaniques et Continentaux) Laboratory, University of Bordeaux 1, France. Sediment structures in cores G10 and G14 were described following the nomenclature by Brodie and Kemp (1994). The lithology of the cores was classified into three categories: "isolated laminae", "irregularly spaced laminae" and "slumped sequences". The "isolated laminae" consisted of solitary diatom ooze (a few mm thick), enclosed in homogeneous mud. The "irregularly spaced laminae" were packs of laminae (several $\mathrm{cm}$ to a few decimeters thick) separated by intervals of homogeneous sediments (several $\mathrm{cm}$ to a few decimeters thick). 
These laminae packs comprised alternations between diatom oozes and diatomaceous mud (with higher contents of clay minerals). Finally, sediment sequences showing internal deformation of the laminae (i.e. unconformable layers and angular discontinuities) were classified as "slumped sequences". While the different types of structures are found throughout the cores, their relative abundances were used to characterize each of the time intervals of interest.

\subsection{Trace element measurements}

Trace elements ( $\mathrm{U}, \mathrm{Mo}, \mathrm{Re}, \mathrm{Cu}$ and $\mathrm{Ni}$ ) concentrations were analyzed by ICP-MS (Ultramass Varian) after hot-plate acid digestion in Polytetrafluoroethylene (PTFE) vessels. Organic matter was eliminated and silicates were removed using acid treatments $\left(\mathrm{HF}, \mathrm{HNO}_{3}\right.$ and $\mathrm{HClO}_{4}$; Jarvis et al., 1992). A detailed description of the methodology employed is described in Salvatteci et al. (2014b). The accuracy of the trace element concentration measurements was determined by comparison with MESS-3 (Marine sediment reference material for trace elements, National Research Council of Canada). The measurement precision was determined by performing duplicate analyses. The average values of replicate digestions were well within the recommended ranges with relative standard deviations (RSD) being $<1 \%$ for $\mathrm{Mo}, \mathrm{U}, \mathrm{Ni}$, and $\mathrm{Cu}$, and $<2.5 \%$ for $\mathrm{Re}$.

The chemical composition of andesite is an appropriate representation of the detrital background of the sediments along the Peruvian margin (Böning et al., 2004; Scholz et al., 2011). We therefore used the element contents of andesite to obtain the authigenic concentration of each trace element taken from the GEOROC database (Sarbas and Nohl, 2009), taking into account the element concentrations in andesite from whole rocks from the central Andean volcanic zone in Peru. Rhenium concentration in andesite displays the lowest values of all metals studied in the present work (100-176 ppt; Alves et al. 2002). The trace elements to aluminum mass ratios in andesite are as follows: $\mathrm{Ni} / \mathrm{Al} \times 10^{-4}=2.55, \mathrm{Cu} / \mathrm{Al} \times 10^{-4}$ $=4.39, \mathrm{U} / \mathrm{Al} \times 10^{-4}=0.34, \mathrm{Re} / \mathrm{Al} \times 10^{-9}=1.93$, and $\mathrm{Mo} / \mathrm{Al} \times 10^{-4}=0.25$. Then, the detrital metal fraction was calculated as: $\mathrm{X}_{\text {detrital }}=(\mathrm{X} / \mathrm{Al})_{\text {andesite }} * \mathrm{Al}_{\text {sample }}$. Finally, the authigenic fraction of element $X$ in a sample was calculated as $X_{\text {total }}-X_{\text {detrital }}$. We calculated the enrichment factor $(\mathrm{EF})$ of the elements to determine if they are depleted or enriched relative to andesite. The EFs were calculated using the formula: $\mathrm{EF}_{\text {element } \mathrm{x}}=(\mathrm{X} / \mathrm{Al})$ sample / (X/Al) andesite (Tribovillard et al., 2006). If EFx is > $>$ (<) 1, then the element $\mathrm{X}$ is enriched (depleted) relative to andesite. 


\section{$4.4 \delta^{15} \mathrm{~N}$ measurements}

Water column denitrification was inferred through $\delta^{15} \mathrm{~N}$ measurements of sedimentary organic matter. The analyses for cores G10 and G14 were performed in the Department of Geosciences at the University of Arizona, USA. $\delta^{15} \mathrm{~N}$ values were measured in untreated sediment samples (i.e. no acidification methods were used) on a continuous-flow gas-ratio mass spectrometer (Finnigan Delta PlusXL) coupled to an elemental analyzer (Costech). Standardization was based on laboratory standard acetanilide and the precision was better than $\pm 0.2(1 \mathrm{~s}) . \delta^{15} \mathrm{~N}$ data from core B14 were published previously by Salvatteci et al. (2014b).

\subsection{Organic matter quantification and characterization}

Total organic carbon (TOC) reflects the amount of organic carbon present in the sediment and can be used to infer past export production. The quantification and characterization of organic matter were done using Rock-Eval 6 (Lafargue et al., 1998). During a programmed pyrolysis, three fractions (S1, S2 and S3) are identified. S1 represents the thermo-vaporized free hydrocarbons contained in the sample released during the isothermal temperature step at $300{ }^{\circ} \mathrm{C}$; S2 represents the hydrocarbons resulting from the cracking of sedimentary organic matter, released between 300 and $650{ }^{\circ} \mathrm{C}$; and $\mathrm{S} 3$ represents $\mathrm{CO}_{2}$ generated at temperatures up to $390^{\circ} \mathrm{C}$ (Lafargue et al., 1998; Behar et al., 2001; Peters, 2005). TOC is determined by summing the pyrolysable organic carbon (i.e. $\mathrm{S} 1+\mathrm{S} 2+\mathrm{S} 3$ ) and the residual organic carbon (Behar et al.; 2001). Normalization of TOC to the concentration of a refractory element (e.g. $\mathrm{Al})$ may correct for variable dilution effects and has the potential to give estimates of organic material input (Martinez and Robinson, 2010). The hydrogen index (HI, mg HC/g TOC) is an indicator of organic matter preservation. It reflects the amount of hydrocarbons released during pyrolysis and is calculated as $\left(\mathrm{S} 2 \mathrm{xTOC}^{-1}\right) \times 100$. The H-rich organic matter is the most labile and thus will be the first to be consumed by aerobic and anaerobic decomposition (Dean et al., 1994). High values of HI (>400 mg HC.g-1 TOC) are interpreted as an indicator of enhanced preservation of lipid-rich organic matter (Arthur et al., 1998).

\section{RESULTS}

\section{$5.1 \delta^{15} \mathrm{~N}$ record}

There were large changes in $\delta^{15} \mathrm{~N}$ values during the last $\sim 25 \mathrm{kyr}$ with higher (lower) values during globally warm (cold) periods at different timescales, except during the globally 
warm mid-Holocene, where low $\delta^{15} \mathrm{~N}$ values were recorded (Fig. 2A). Both the Early Glacial (23-26 kyr BP) and the LGM (19-23 kyr BP) were characterized by low $\delta^{15} \mathrm{~N}$ values (Table 1). From 18.4 to $16.6 \mathrm{kyr} \mathrm{BP}$, there was an increase from 6.2 to $11.4 \%$ in $\delta^{15} \mathrm{~N}$. During this period, the high $\delta^{15} \mathrm{~N}$ values exhibited strong multi-centennial-scale variability, followed by a gradual decrease. The Early Holocene was characterized by relatively high $\delta^{15} \mathrm{~N}$ values, followed by a tendency towards lower $\delta^{15} \mathrm{~N}$ values, reaching a mid-Holocene $(\sim 6.5 \mathrm{kyr} \mathrm{BP})$ minimum of $4.8 \%$. The rest of the mid-Holocene was characterized by very low $\delta^{15} \mathrm{~N}$ values. During the Late Holocene, $\delta^{15} \mathrm{~N}$ values exhibited temporal variability from $\sim 3$ kyr BP onwards: low $\delta^{15} \mathrm{~N}$ values (5.2\%) were achieved during the LIA, as low as during the MidHolocene, and the highest values (10\%), as high as during the Termination 1 period, during the LIA - Current Warm Period (CWP) transition. Although $\delta^{15} \mathrm{~N}$ values increased again during the last 150 years, the average for the last 100 years remained relatively low $(6.7 \pm 0.3 \%)$ compared to the entire record.

\subsection{Lithology of the composite record}

Sediments from H1S, the Early and the Late Holocene showed more laminations compared to sediments from the Early Glacial, the LGM and the mid-Holocene (Fig. 2B). The most common sediment structures observed in the cores were the "irregularly spaced laminae", "isolated laminae" and "slumped sequences" (see supplementary material for details). The "irregularly spaced laminae" that contained finely laminated sequences were present throughout the record, but were better preserved during the H1S, and the Early and Late Holocene. By contrast, during the Early Glacial and the LGM the "isolated laminations" (which include banded sequences) were more frequent, even though laminated sequences were also sporadically observed (e.g., at $\sim 25 \mathrm{kyr}$ BP). Finally, the mid-Holocene was characterized by the absence of finely laminated sequences, the presence of isolated laminations, and sequences that contained reworked material.

\subsection{Trace element record}

\subsubsection{Data presentation}

In the present study, we show trace element values as EFs (Enrichment Factors). Normalization of trace element concentrations as a ratio with $\mathrm{Al}$, or the calculation of EFs may increase, decrease or even change the sign of the correlations between unmodified variables (Van der Weijden, 2002). Subtle changes in some correlations between concentrations and normalized variables were observed (Table 2 and 3). In some cases, the 
correlation variables were slightly higher in the normalized data set (e.g. correlation between trace elements and TOC), most likely as a result of having the same common denominator (Al). By contrast, weak correlations between unmodified variables were weaker in the normalized dataset (e.g., correlation between $\delta^{15} \mathrm{~N}$ and trace elements). Thus, in order to minimize the normalization biases we focus on stratigraphic variation in EFs rather than on absolute values as suggested by Tribovillard et al. (2006). Nonetheless we calculated the average EF of each element in the whole record to identify the elements with highest enrichment relative to andesite (Table SM2). Re and Mo showed high EFs (373 \pm 167 and $34.7 \pm 30.6$ respectively), $\mathrm{U}$ and $\mathrm{Ni}$ showed moderate enrichment $(5.9 \pm 3.4$ and $4.3 \pm 2.5$ respectively) and finally $\mathrm{Cu}$ showed low enrichment $(1.1 \pm 0.7)$.

\subsubsection{Temporal variability of the trace elements}

The EFs of the trace elements $\mathrm{U}, \mathrm{Re}, \mathrm{Mo}, \mathrm{Ni}$, and $\mathrm{Cu}$ showed pronounced variability during the last $25 \mathrm{kyr} \mathrm{BP}$ (Fig. 2C to G; authigenic concentrations of each element: Figure SM7, complete data set Table SM2). Uranium and Re showed similar enrichment patterns, with their concentrations being higher than andesite throughout the core. Mo was enriched throughout the core and exhibited low EFs during the glacial-deglacial period and during the mid-Holocene. Nickel and $\mathrm{Cu}$ displayed similar enrichment patterns, with high values during the Holocene and low values (and even depletions) during the glacial-deglacial period. Overall, U, Re, Mo, Ni, Cu showed higher enrichment during the Holocene compared to the glacial-deglaciation period (Fig. 2C to G). There was a striking difference between $\mathrm{U}, \mathrm{Re}, \mathrm{Ni}$ and $\mathrm{Cu}$ on the one hand, and Mo on the other: during the recorded part of the mid-Holocene $\mathrm{U}, \mathrm{Re}, \mathrm{Ni}$ and $\mathrm{Cu}$ showed relatively higher values compared to the glacial-deglacial period and the Early Holocene, whereas Mo showed lower enrichments, which was consistent with the low $\delta^{15} \mathrm{~N}$ values in this part of the record. Moreover, Mo showed the highest correlation with $\delta^{15} \mathrm{~N}$ during the Holocene ( $\left.\mathrm{r}=0.75, \mathrm{n}=153\right)$, compared to that of $\mathrm{U}(\mathrm{r}=0.4, \mathrm{n}=133)$, $\operatorname{Re}$ $(\mathrm{r}=0.30, \mathrm{n}=153), \mathrm{Ni}(\mathrm{r}=0.53, \mathrm{n}=153)$, and $\mathrm{Cu}(\mathrm{r}=0.55, \mathrm{n}=153)$ with $\delta^{15} \mathrm{~N}$. Additionally, during the Late Holocene, all trace elements (as well as $\delta^{15} \mathrm{~N}$ ) exhibited higher temporal variability compared to the preceding periods. The centennial-scale minimum trace metal EFs during the Late Holocene were as low as during the glacial-deglaciation period.

\subsection{Organic matter quantification and preservation}

The TOC/Al values as well as the HI showed large changes throughout the record, with higher values during the Holocene compared to the glacial-deglaciation period (Fig. $2 \mathrm{H}$ 
and I). Low TOC values characterized the Early Glacial $(0.3 \pm 0.1)$ and the LGM $(0.4 \pm 0.1)$ and were associated with low HI values $\left(300 \pm 28,305 \pm 21 \mathrm{mg} . \mathrm{HC} \cdot \mathrm{g}^{-1} \mathrm{TOC}\right.$, respectively). A small increase in TOC was observed during the H1S $(0.6 \pm 0.2)$ and the Antarctic Cold Reversal $(0.6 \pm 0.1)$ which was associated with relatively high HI values $(400 \pm 38$ and $400 \pm 31$ mg.HC. $g^{-1}$ TOC respectively). During the Holocene, there was an increasing trend in average TOC/Al from the Early Holocene to the Late Holocene $(0.9 \pm 0.2,1.2 \pm 0.4$ and $1.4 \pm 0.5)$, strong centennial-scale variability in TOC/Al values is observed during the Late Holocene. The HI values were similar during the Early Holocene, mid-Holocene and Late Holocene (427 $\pm 25 ; 428 \pm 26$ and $427 \pm 3431$ mg.HC.g ${ }^{-1}$ TOC respectively), however strong centennialscale variability in the HI was observed during the Late Holocene. Finally, the CWP exhibited the highest TOC/Al (3.1 \pm 0.3$)$ and HI values (472 \pm 17 mg.HC.g ${ }^{-1}$ TOC). In general, TOC/Al showed high correlations with the trace elements EFs (Table 2 and 3); however, the correlations of TOC (percentages or TOC/Al) with $\mathrm{Ni}$ and $\mathrm{Cu}$ were slightly higher than with Mo, U, and Re.

\section{DISCUSSION}

We used a stacked record covering the last $25 \mathrm{kyr}$ BP, retrieved from the core of the current ETSP-OMZ, to reconstruct changes in water column denitrification, sediment redox conditions, and export production as inferred from a suite of proxies including $\delta^{15} \mathrm{~N}$, presence of laminations, TOC, and redox sensitive metals (Fig. 3). In the following sections, we discuss 1) the use of the sediment record stratigraphy as a proxy for benthic oxygenation, 2) changes in benthic redox conditions and productivity during the last $25 \mathrm{kyr}, 3$ ) a potential mechanism producing oxygenation changes during the glacial times and the deglaciation, 4) potential mechanisms controlling oxygenation and productivity changes in the ETSP-OMZ during the Holocene, and 5) the implications of the present study in the context of current global warming.

\subsection{Assessing the sediment core stratigraphy as a proxy for benthic oxygenation}

The presence of laminations in the stacked record suggests reducing conditions during parts of Termination 1, and the Early and Late Holocene (Fig. 3B). The presence of laminae has been used as strong evidence of low oxygen concentrations off Peru, off California, in the Gulf of California, and elsewhere, but it must be stressed that the absence of laminae, at least 
off Peru, cannot be used as an evidence of high oxygen concentration as suggested in several studies (Brodie and Kemp, 1994; Van Geen et al., 1996; Schönfeld et al., 2015). For example, as illustrated in core B14 (Fig. SM2), the last 100 years of the record show very few distinct laminations but the proxies for water column and sediment oxygenation indicate strong reducing conditions (Salvatteci et al., 2014b). Moreover, finely laminated sequences are sometimes associated with less reducing conditions in the sediments and reduced water column denitrification, as for example during the LIA (Fig. SM2; Gutierrez et al., 2009; Salvatteci et al., 2014b). The absence of laminae is not simply related to increased bottomwater oxygenation, but more likely to a complex interplay of factors including turbidite flows, slumps, winnowing by strong currents, bioturbation, and a lack of regular variation in terrigenous and biological material (Salvatteci et al., 2014a). Thus, whereas the presence of laminae is a reliable indicator of reducing conditions, the absence of laminae as a proxy of enhanced oxygenation needs to be validated with other proxies such as redox-sensitive metals.

\subsection{Oxygenation and export production changes during the last $25 \mathrm{kyr}$}

\subsubsection{Molybdenum EF, and Mo and U EFs ratios}

The use of $\mathrm{Mo}_{\text {auth }}$ concentrations or EFs in the core of the ETSP-OMZ is a useful tool to draw inferences concerning paleoredox conditions since the uptake of Mo by the sediments is mainly driven by benthic redox conditions (Algeo and Tribovillard, 2009; Scholz et al., 2011, Scholz et al., 2014). The operation of the particulate Mn-Fe-oxyhydroxide shuttle is an important mechanisms in sediments from the Peruvian shelf, scavenging Mo from the water column, and raising its concentration near the sediment surface, promoting its diffusion to the sediments (Scholz et al., 2011; Helz and Adelson, 2013). In the core of the OMZ ( 300 m depth), sediments receive little Mn-bound particulate Mo, since Mn reduction is largely completed in the water column and Mo pore-water profiles at this depth indicate a downward flux to the sediments (Scholz et al., 2011). Although the evolution of aqueous trace-metal chemistry is an important mechanism in, e.g., the Black Sea, it is not significant in open marine systems like the ETSP (Algeo and Tribovillard, 2009).

The Mo EFs plot indicated less reducing conditions during the Early Glacial, LGM and the deglaciation periods, whereas strong reducing conditions prevailed during parts of the 
595 Early, mid- and Late Holocene (Fig. 3C). In our stacked record, high Mo EFs (Fig. 2C) 596 coincide with good organic matter preservation (Fig. 2I), suggesting that an increase in Mo $597 \mathrm{EF}$ (and other trace elements) is mainly driven by changes in redox conditions and not by an 598 increase in organic matter decomposition. During the Early Glacial, LGM, H1S, and ACR, 599 the Mo EFs were relatively low but enriched relative to andesite, suggesting less reducing 600 conditions compared to the Early and Late Holocene (Table SM2). However, there were two 601 multidecadal-scale maxima during the H1S (at 17.03 and $15.39 \mathrm{kyr} \mathrm{BP}$ ) with EFs similar to 602 those observed during the Holocene (Table SM2). On average, the Early and Late Holocene 603 showed more reducing conditions compared to the recorded part of the Mid-Holocene (Fig. 604 3C). Finally, the Late Holocene exhibited strong centennial-scale variability in Mo EFs, with 605 shifts from sub-oxic to anoxic benthic redox conditions.

606

Concordant with the Mo EF record, the cross-plot of Mo versus U EFs shows that 608 sediments from the Early Glacial, LGM and ACR were sub-oxic whereas sediments from the H1S, Early Holocene, mid-Holocene and Late Holocene were anoxic and in some cases sulfidic (Fig. 4). Cross-plots give additional insights of past redox oscillations, as in sediments of the OMZ core the relationship of redox conditions to authigenic Mo-U enrichment is straight forward: 1) suboxic conditions result in sediments with modest Mo and $\mathrm{U}$ enrichments, and with $(\mathrm{Mo} / \mathrm{U})_{\text {auth }}$ ratios lower than the seawater ratio, and 2) anoxic conditions result in sediments with strong $\mathrm{Mo}$ and $\mathrm{U}$ enrichments accompanied by progressively higher $(\mathrm{Mo} / \mathrm{U})_{\text {auth }}$ ratios as total authigenic concentrations increase (McManus et al., 2006; Algeo and Tribovillard, 2009; Scholz et al., 2011). During the Early Glacial, $\mathrm{LGM}$, and $\mathrm{ACR},(\mathrm{Mo} / \mathrm{U})_{\text {auth }}$ ratios below the concentration of seawater were recorded, as a consequence of modest U EFs, but relatively lower Mo EFs (Fig. 2C and E). By contrast, during (at least parts of) the H1S, Early, Mid- and Late Holocene, (Mo/U) auth ratios were sometimes 3 times above the ratio of these elements in seawater. The pattern of redox variations from the sediments of the present study (Fig. 4) is very similar to multiple continental margin sites in the Eastern Tropical Pacific (Algeo and Tribovillard, 2009), further indicating that the $(\mathrm{Mo} / \mathrm{U})_{\text {auth }}$ ratio is a valid proxy for reconstructing changes in benthic redox conditions. Moreover, no evidence for an enhanced Mo supply with metal (oxyhydr)oxides (i.e. particule shuttle) has been found (Algeo and Tribovillard, 2009; Scholz et al., 2011). 
Multidecadal to centennial-scale periods characterized by sulfidic conditions in the sediments where reached several times during the last $25 \mathrm{kyr}$, as indicated by the $(\mathrm{Mo} / \mathrm{U})_{\text {auth }}$ and Mo EFs (Figs. 3C, D and 4). A shift from suboxic to sulfidic benthic redox conditions enhances uptake of both Mo and $\mathrm{U}$, but a stronger accumulation of Mo results in a disproportional increase in the $(\mathrm{Mo} / \mathrm{U})_{\text {auth }}$ ratio. A preferential uptake of $\mathrm{U}$ over Mo takes place when redox conditions at the sediment/water interface are suboxic, and of Mo over U when benthic redox conditions are strongly and/or frequently sulfidic (Algeo and Tribovillard, 2009). The (Mo/U) auth record shows values below the seawater ratio during the Early Glacial, LGM, and during ACR indicating suboxic conditions, whereas the higher values during parts of the H1S, Early mid-and Late Holocene indicate sulfidic conditions (Fig. 3D). The mid-Holocene shows $(\mathrm{Mo} / \mathrm{U})_{\text {auth }}$ ratios slightly above the seawater ratio suggesting more reducing conditions compared to the Early Glacial and LGM, but less reducing conditions compared to the $\mathrm{H} 1 \mathrm{~S}$, and parts of the Early and Late Holocene. The high Mo EFs (up to 230), during periods of poor oxygenation in the Early and Late Holocene were the result of strong sulfidic conditions in the near-surface sediment (Scholz et al., 2014). Finally, the last 100 years show strong sulfidic conditions (inferred by the high Mo EFs, Fig., 3C), and indicate that these conditions were not unprecedented.

\subsubsection{Rhenium-molybdenum ratios}

The Re/Mo ratio can potentially be used to distinguish between suboxic and sulfidic conditions in the sediments given the different behavior of $\mathrm{Re}$ and Mo under reducing conditions (Crusius et al., 1996). Sediments that are enriched in Re and/or Mo with a Re/Mo ratio higher than the seawater ratio $\left(0.4 \mathrm{ng} \cdot \mathrm{ug}^{-1}\right)$ were deposited under suboxic conditions, while Re/Mo ratios equal to or less than the seawater value were deposited under sulfidic conditions (Crusius et al., 1996). However, interpretations derived from Re/Mo ratios should be taken with caution, for example Re and Mo accumulations from a core retrieved from the OMZ in the Eastern Tropical North Pacific suggested anoxic conditions, but Re/Mo ratios suggested intermediate reducing conditions (Nameroff et al., 2002). Thus, Re/Mo ratios should be used in combination with other redox sensitive proxies to infer past reducing conditions (Nameroff et al., 2002; Morford et al., 2005).

The interpretations from the Re/Mo record are strikingly concordant with those derived from the Mo EF and the Mo/U ratio (Fig. 3E). High Re/Mo ratios (and relatively low 
Mo and Re EFs), indicative of suboxic conditions, characterize the Early Glacial and LGM, which is also in agreement with the poor laminae preservation and low Mo/ $\mathrm{U}$ ratios (Fig. 3B and D). The start of the H1S showed a Re/Mo decline to ratios below the seawater ratio and then a trend towards increased values until the end of the ACR, interrupted by low values around $\sim 15.4 \mathrm{kyr}$ BP (Table SM2). The relatively high Re/Mo ratios from $\sim 16.5$ to $13.5 \mathrm{kyr}$ $\mathrm{BP}$, indicative of suboxic conditions, is consistent with relatively low Mo EFs and Mo/U ratios. On average, the Early $(0.9 \pm 0.3)$ and Late Holocene $(0.3 \pm 0.1)$ showed lower Re/Mo ratios compared to the recorded part of the mid-Holocene $(1.2 \pm 0.3)$. The high Re/Mo ratios during the mid-Holocene suggests more reducing conditions compared to the Early Glacial and LGM, but less reducing conditions compared to the H1S, and parts of the Early and Late Holocene, as also suggested by the (Mo/U) auth ratios (Fig. 3D).

The combined evidence from the lithology of the record, Mo EFs and Mo/U records (Fig. 3) support the use of Re/Mo to distinguish between suboxic and sulfidic conditions in sediments from the ETSP. While the $\mathrm{Mo} / \mathrm{U}$ systematics has been commonly used to distinguish between suboxic and sulfidic conditions (e.g., Algeo and Tribovillard, 2009; Scholz et al., 2014), only a few studies have used the Re/Mo systematics for this purpose (e.g., Salvatteci et al., 2014b). The use of Re/Mo systematics is promising because Re and Mo show the highest degree of enrichment in reducing sediments relative to crustal values in the ETSP, as well as and in other reducing settings (Crusius et al., 1996; Nameroff et al., 2002; Böning et al., 2004). The signal is best-preserved when buried rapidly (Crusius et al., 1996), and it appears that Re accumulation in sediments is solely due to the extent of reducing conditions (Morford et al., 2005).

\subsubsection{Coupling-decoupling between water column denitrification and sediment redox conditions}

The large changes in the intensity of water column and benthic redox conditions showed a similar pattern during most of the record except from the ACR, indicating a strong coupling between water column denitrification and sediment redox conditions (Fig. 3). The weak water column denitrification (Fig. 3A) during the Early Glacial and the LGM is consistent with the suboxic conditions inferred from the Mo EF, the Mo/U and the Re/Mo ratio, and the banded nature of the sediments (Fig. 3B to E). During the Holocene, the $\delta^{15} \mathrm{~N}$ (Fig. 3A) and the Re/Mo ratios (Fig. 3D) are strongly correlated ( $r=-0.74, n=153, p<0.005)$, 
implying a strong coupling between water column denitrification and sediment redox conditions. The more laminated nature of the sediments during the Early and Late Holocene and the presence of bands and more homogeneous sediments during the mid-Holocene (Fig. 3B) are also consistent with the $\delta^{15} \mathrm{~N}$ values, and the $\mathrm{Mo} / \mathrm{U}$ and Re/Mo ratios. In general, this implies a strong coupling between water column denitrification and benthic redox conditions during the Early Glacial, LGM, and the Holocene. By contrast, the strong water column denitrification during the ACR (Fig. 3A) is clearly opposed to the less reducing conditions in the sediments (Fig. 3B to E) inferred from the lithology and the redox sensitive metals, indicating a decoupling between water column denitrification and benthic sediment redox conditions. Taken together, the proxies indicate a stronger OMZ during the H1S, Early and Late Holocene, and a weaker OMZ during the glacial periods and during the mid-Holocene (Fig. 3). During the ACR, the decoupling between water column denitrification and sediment redox conditions suggests a strong but shallow OMZ.

\subsubsection{Export production changes and coupling-decoupling between productivity and oxygenation}

Nickel has recently been recognized as an indicator of the organic sinking flux in sediments from upwelling regions (Böning et al., 2015). It has been shown that Ni 1) is associated with enzymes involved in photoautotrophic production, and 2) is a proxy for the original chlorophyll flux to the sediments (Böning et al., 2015). The strong correlation $\left(\mathrm{r}^{2}>\right.$ 0.80) between $\mathrm{Ni}$ with TOC in organic-rich sediments from upwelling systems of Peru, Namibia, Chile and from the Gulf of California suggests that $\mathrm{Ni}$ is a clear indicator of the organic sinking flux (Böning et al., 2004; 2015). The preferential preservation of Ni over TOC in Peru sediments strongly supports paleo-productivity estimates based on Ni EFs (Tribovillard et al., 2006; Böning et al., 2015). In this sense, $\mathrm{Ni}$ is a better indicator of export production than $\mathrm{Cu}$ because $\mathrm{Ni}$ is less affected by secondary overprints related to sulfur cycling (Böning et al., 2015). Nickel EFs are likely to represent the original presence of organic matter even if it is partially lost after deposition (Tribovillard et al., 2006), as likely occurred in several samples of our composite record associated with poor organic matter preservation (Fig. 2I).

The export production, represented by the Ni EF, showed a similar pattern to other redox sensitive proxies throughout the record: lower values during the last glacial-interglacial 
transition and high values (with high temporal variability) during the Holocene (Fig. 3F). Very low export production characterized the Early Glacial and the LGM. The start of the H1S (17-18 kyr BP) showed a small increase in productivity compared to the earlier periods, but from 17-14.5 kyr BP export production was low and comparable to the Early Glacial and the LGM. In some samples of the Early Glacial and LGM, Ni and especially $\mathrm{Cu}$ were depleted relative to andesite (Fig. $2 \mathrm{~F}$ and G), but this is likely to be a result from the masking of the non-lithogenic metal component by rather high lithogenic metal concentrations (Table SM1; Böning et al., 2015). The Early Holocene and mid-Holocene were characterized by higher export production compared to the last glacial-interglacial transition. During the Early Holocene, the export production did not show the strong multi centennial-scale variability observed during the Late Holocene. Finally, from $\sim 4$ kyr BP to the present, a positive trend towards higher export production with strong multi-centennial scale variability is observed (Fig 3F).

Oxygen demand as a result of local export production exerted a strong signal in water column denitrification and sedimentary redox conditions in the ETSP-OMZ; however, in the case of several remarkable exceptions the regional signal (i.e. remote factors) dominated the record (Fig. 3). Export production, as inferred by Ni EFs, was strongly coupled with water column denitrification during the ACR ( $\mathrm{r}=0.69, \mathrm{n}=13)$, Early Holocene $(\mathrm{r}=0.70, \mathrm{n}=35)$, and Late Holocene ( $\mathrm{r}=0.69, \mathrm{n}=83$ ), but not during the Early Glacial ( $\mathrm{r}=0.32, \mathrm{n}=19)$, LGM ( $\mathrm{r}=0.28$, $\mathrm{n}=18)$, the H1S ( $\mathrm{r}=0.24, \mathrm{n}=65)$, and the mid-Holocene $(\mathrm{r}=0.27, \mathrm{n}=35)$. These findings suggest that the original $\delta^{15} \mathrm{~N}$ signal of the water masses reaching the ETSP during the Early Glacial, LGM, H1S, and mid-Holocene was not significantly modified by the effect of local export production. By contrast, during the ACR, Early Holocene and Late Holocene, oxygen demand as a result of local export production, likely exerted a strong impact on the $\delta^{15} \mathrm{~N}$ signal. Additionally, export production and benthic oxygenation (indicated by the Re/Mo ratio) were coupled during the Early Holocene $(r=0.57, n=35)$ and Late Holocene $(r=0.58, n$ $=118$ ), but not during the Early Glacial $(r=0.32$, $n=19)$, LGM ( $r=0.47, n=18), H 1 S(r=0.4$, $\mathrm{n}=65)$, the ACR $(\mathrm{r}=0.07, \mathrm{n}=13)$, and the mid-Holocene $(\mathrm{r}=0.32, \mathrm{n}=61)$. These results indicate that during the Early and Late Holocene, export production, water column denitrification, and sediment redox conditions were strongly coupled; the high export production likely exerted a strong influence on the water column denitrification and benthic redox conditions. By contrast, during the LGM, H1S, ACR, and mid-Holocene, remote factors may have controlled water column denitrification and sediment redox conditions. 
6.3 High latitude processes driving oxygenation changes during glacial times and the deglaciation

The good match among low $\delta^{15} \mathrm{~N}$ values, lack of laminae preservation, low Mo EFs, low $\mathrm{Mo} / \mathrm{U}$ and high $\mathrm{Re} / \mathrm{Mo}$ ratios provides very strong evidence of low denitrification in the water column and less reducing conditions in the surface sediments, implying a weaker OMZ during the Early Glacial and the LGM (Fig. 5A and B). These results are in agreement with $\delta^{15} \mathrm{~N}$ records along the Central and South American margin between $15^{\circ} \mathrm{N}$ and $36^{\circ} \mathrm{S}$, which suggest weak water column denitrification and thus a weaker OMZ during the glacial periods (Robinson et al., 2007; 2009; Martinez and Robinson, 2010). Reduced water column denitrification during the glacial periods is attributed to reduced upwelling, decreased export productivity, and consequently to a lower oxygen demand along the continental margin of the Americas (Ganeshram et al., 2000). This is in agreement with our record of export production (Fig. 5C), reinforcing the idea of low productivity and thus lower oxygen demand, with a negligible signal on water column denitrification. Additionally to the reduced upwelling, the lower surface temperature during glacial stages increased oxygen solubility, while stronger winds in high-latitude regions enhanced the rate of thermocline ventilation (Galbraith et al., 2004). Moreover, sediment redox metals in sediment cores off Chile (e.g., core ODP-1235, Fig. 1B) indicate relatively high pore-water oxygen concentrations during glacial intervals (Fig. 5D; Muratli et al., 2010; Chase et al., 2015); this implies a weak OMZ in the ETSP during glacial times and consistent with our findings.

The decoupling between water column denitrification and sediment redox conditions during the ACR periods suggests that an extra-tropical process was responsible for oxygenation of the bottom waters. A possible explanation for the less reducing conditions during the ACR was an increase in flow of the Antarctic Intermediate Water (AAIW), which is characterized by high $\mathrm{O}_{2}$ values (Fig. 1B). The AAIW is a dominant southern hemisphere water mass that spreads from its formation regions north from the Antarctic Circumpolar Current to at least $20^{\circ} \mathrm{S}$ into all oceans (Schmidtko and Johnson, 2012); however, it was hypothesized that during the deglaciation the AAIW penetrated much further northward than today (Marchitto et al., 2007, Basak et al., 2010). The increase in AAIW flow was likely produced by an increase in Southern Ocean upwelling during the Termination 1 period as demonstrated by enhanced diatom productivity in the Southern Ocean (Fig. 5E; Anderson et 
al., 2009). This enhanced upwelling in the Southern Ocean coincided with the deglacial warming in Antarctica and the rise in atmospheric $\mathrm{CO}_{2}$ (Anderson et al., 2009). Radiogenic isotope compositions of neodymium from a sediment core collected off Baja California also showed an AAIW signal during the H1S and ACR (Fig. 5F; Basak et al., 2010), supporting the hypothesis of an AAIW strengthening during these periods. Our record is consistent with the hypothesis of an increase in AAIW flow: it appears that during the Termination 1 period, the ETSP-OMZ was strong, as evidenced by our $\delta^{15} \mathrm{~N}$ record (Fig. $5 \mathrm{~A}$ ) and several other $\delta^{15} \mathrm{~N}$ records (e.g., Higginson and Altabet, 2004; Martinez et al., 2006; Galbraith et al., 2013; Jaccard and Galbraith, 2013). However, during part of the Termination 1 period, the sediment floor in the ETSP-OMZ was in contact with relatively more oxygenated water, indicating that the OMZ was shallower than at present. The lower boundary of the OMZ was located at a depth of at least 350 meters, taking into account the sea level changes at those time periods and the present position of core G14 (Fig. 1B).

\subsection{Factors controlling oxygenation and productivity changes in the ETSP during the Holocene}

We hypothesize that the enhanced oxygenation of the ETSP-OMZ during the midHolocene (Fig. 5A and B) was produced by an intensification of the equatorial subsurface countercurrents (EUC, SICC and SSCC, Fig. 1A) that brought more oxygenated waters to Western South America. At present the secondary SSCC carries a water mass with low $\delta^{15} \mathrm{~N}$ (5.5 $\pm 0.3 \%$; Rafter et al., 2012), which is very similar to the $\delta^{15} \mathrm{~N}$ values during the midHolocene ( $6 \pm 0.8 \%$, Fig. $5 \mathrm{~A})$. A potential mechanism that would explain the intensification of the equatorial subsurface countercurrents could be related to a strengthening of the Walker circulation during the Early and mid-Holocene. The Walker circulation strengthening was a result of an enhanced zonal SST gradient across the tropical Pacific from 9 to $5 \mathrm{kyr}$ BP (Koutavas et al., [2006]; see Fig. 1A). Moreover, a more northerly position of the ITCZ in the eastern Pacific during the mid-Holocene (Mollier-Vogel et al., 2013) may have favored more permanent southeast trades and promoted increased upwelling in the Eastern Tropical Pacific (Koutavas et al., 2006). During the mid-Holocene, the Southern westerlies were situated in a poleward position (Lamy et al., 2001; Jenny et al., 2002), suggesting an expanded South Pacific Anticyclone (SPA) and a strengthening of the Hadley circulation, which resulted in strong alongshore winds off Peru. Thus, as a result of a stronger Walker circulation, the subsurface equatorial currents accelerated mainly due to sea level differences in the western 
and eastern Pacific. Moreover, stronger alongshore coastal winds, as a result of increased trade winds, may also have contributed to the oxygenation of the upper layers of the water column by enhanced vertical mixing, which resulted in a weakening of the OMZ.

Indirect evidence based on the lithology of multiple sediment cores retrieved off Peru support the hypothesis of a stronger PUC during the Early and mid-Holocene. Multiple sediment cores that contained Holocene sequences retrieved along the Peruvian margin show winnowed sequences and temporal gaps from $\sim 3$ to $\sim 8 \mathrm{kyr}$ BP (Reinhardt et al., 2002; Skilbeck et al. 2006; Makou et al., 2010; Schönfeld et al., 2015). For example, sediment cores 1229E, 106KL, and 1228D from the central-Peruvian shelf (Fig. 1B), retrieved between 150 and 250 meters depth, show low sediment accumulation during the mid-Holocene. By contrast, the sediment cores used in the present work and another core taken at $15^{\circ} \mathrm{S}$ (Fig. 1B; Chazen et al., 2009), all from deeper depths, do not show large gaps during the midHolocene. Currently, the core of the PUC between $9{ }^{\circ} \mathrm{S}$ and $15^{\circ} \mathrm{S}$ is centered inshore of the shelf break in contact with the sediment floor, whereas south from $15^{\circ} \mathrm{S}$ the PUC core is detached from the slope (Chaigneau et al., 2013). During the mid-Holocene the PUC was likely more intense than today and eroded sediment sequences in the central and northern part of the Peruvian margin. Thus, the evidence suggests a stronger PUC during the globally warm mid-Holocene probably reinforced by the strengthening of the equatorial undercurrents.

By contrast, the Late Holocene is characterized by a strong yet temporally variable OMZ. This can be partially explained by a reduction of the SST gradient (Koutavas et al., 2006) and a reduced influence of the equatorial undercurrents. Around 4 kyr BP, the eastern Pacific started to warm while the western Pacific warm pool experienced a cooling of comparable magnitude, marking the transition to a climate regime more typical of present day conditions (Koutavas et al., 2006). The strong centennial-scale variability of productivity and oxygenation during the last 4 kyr may have been the result of more subtle changes in the expansion/contraction of the SPA and the strength of the Walker circulation (Salvatteci et al., 2014b) compared to the changes observed during the mid-Holocene. The position of the Southern Hemisphere westerlies, and thus the southern boundary of the SPA, is thought to be partially controlled by changes in solar forcing, with higher (lower) solar activity producing a poleward (equatorward) shift of the annual mean westerlies (Varma et al., 2011). A SPA expansion during the global warm periods (e.g. MCA and CWP) drove an increase in 
upwelling off Peru of low oxygen and high nutrient waters, promoting productivity, and finally consuming oxygen in the water column from the decay of organic matter (Salvatteci et al., 2014b). The increasing trend of productivity during the last $\sim 4 \mathrm{kyr}$ probably resulted from an increase in insolation (Fig. 5C). Currently, the productivity off Peru is higher in summer and spring when the water column is more stratified (Gutierrez et al., 2011), thus an increase in spring-summer insolation may have promoted productivity. The observed increase in centennial scale variability in OMZ intensity and export production during the Late Holocene is consistent with other climate reconstructions from the Eastern tropical Pacific indicating a more variable Eastern Tropical Pacific in the Late Holocene (Moy et al., 2002; Koutavas et al., 2006; Conroy et al., 2008; Chazen et al., 2009).

\subsection{Implications of the present study}

The combined results of this work and from the literature suggest a weaker OMZ and a less productive Peruvian upwelling ecosystem in a warmer world. While the stronger Walker circulation in the Tropical Pacific during the mid-Holocene is not an ideal analogue to present global warming due to different forcing it can be seen as a potential future scenario. The mid-Holocene (also known as Holocene Climatic Optimum) was a period of high temperature in the northern hemisphere in response to high latitude orbital forcing. This was reflected in the Tropical Pacific in a stronger Walker circulation produced by a strong SST zonal gradient $1.5{ }^{\circ} \mathrm{C}$ higher than today (Koutavas et al., 2006). Reservoir ages and coastal SSTs off Peru suggest that the coastal upwelling intensity off Peru was stronger during the mid-Holocene than during the modern La Niña phases (Carré et al., 2012), however the stronger upwelling did not produce higher productivity. Additionally, a stronger Walker circulation during the mid-Holocene probably intensified the equatorial subsurface countercurrents, bringing oxygen-rich waters to intermediate depths in the ETSP. This observation is at odds with climate models that predict that oceanic dissolved oxygen decline will continue in the future (Keeling et al., 2010).

Increasing evidence suggests that during the past few decades the Walker circulation strengthened (Luo et al., 2012; L'Heureux et al., 2013) and the SPA intensified (Falvey and Garreaud, 2009). Moreover, observational data and paleoceanographic reconstructions suggest a strengthening in wind intensity in eastern boundary upwelling systems (Bakun, 1990; Vargas et al., 2007; Gutierrez et al. 2011). While the current environmental 
configuration in the Peru-Chile Upwelling Ecosystems are ideal for marine productivity, it appears that further warming will drive the Peruvian upwelling ecosystem out of the current "sweet spot" (Bakun and Weeks, 2008), with profound effects on society and economy. The large changes in OMZ intensity at different timescales during the last $25 \mathrm{kyr} \mathrm{BP}$, triggered by both local and remote forcings, suggest that the decrease in oxygen observed during the last -50 years is not unprecedented when compared to the geological record. Conclusive statements about the response of the biota to future OMZ intensification could be done by evaluating the response of the communities to past changes in oxygenation.

\section{CONCLUSIONS}

Water column denitrification and sediment redox conditions show large changes during the last $25 \mathrm{kyr}$, making the current oxygenation levels in the last 50 years in the ETSPOMZ not unprecedented. Global cold periods during the LGM (23 to $19 \mathrm{kyr}$ BP) and the LIA (1500 to $1850 \mathrm{AD}$ ) are generally associated with a weak OMZ, while warm intervals such as the deglaciation, part of the MCA and the last 100 years are associated with a stronger OMZ. The presence of sulfidic conditions in the sediments, as observed for the last $50 \mathrm{yr}$, is not a unique feature for the current warm period since it was sporadically observed in the record associated with high export production levels.

Extra-tropical forcings and equatorial climate variability were the major drivers of the subsurface ventilation and productivity off Peru during the last $25 \mathrm{kyr}$. Changes in oxygenation in the sediment-water interface and the water column were strongly coupled during the last $25 \mathrm{kyr}$ BP with a remarkable exception during part of the last deglaciation. The results indicate that remote forcings from high latitudes and changes in equatorial dynamics regulated directly or indirectly the intensity and vertical/horizontal extension of the OMZ.

The weak ETSP-OMZ during the mid-Holocene is not an ideal analogue for present global warming but it can be seen as a potential future scenario. An expanded SPA and a stronger Walker Circulation during the mid-Holocene produced stronger upwelling off Peru but did not favor productivity. Additionally, a stronger Walker circulation during the warm mid-Holocene probably intensified the equatorial undercurrents, bringing oxygen-rich (and hence nutrient-poor) waters to intermediate depths off Peru dampening productivity. 
Observational data from the last few decade suggest a strengthening of the Walker circulation, an expansion of the SPA and increased alongshore winds off Peru. While the current environmental configuration in the Peru-Chile Upwelling Ecosystems are ideal for marine productivity, further warming may reduce productivity in the Peruvian Upwelling Ecosystem with profound effects on society and economy.

\section{ACKNOWLEDGMENTS}

We deeply thank the "Institut de Recherche pour le Développement" for granting a $\mathrm{PhD}$ scholarship to RS during which most of the analyses were done. We deeply thank Bo Thamdrup, chief scientist of the Galathea-3 expedition (Leg 14), and Bente Lomstein, who conducted the core sampling onboard the RV Vaedderen. We also sincerely thank F. Le Cornec, J. Cottet and I. Djouraev (IRD-Bondy and LOCEAN) for their most appreciated help with the ICP-MS analyses. We thank P. Martinez for providing the SCOPIX and photograph images. We thank F. Scholz and B. Schneider for constructive discussions. We are grateful to R. Gingold (sweepandmore.com) for a thorough revision of the manuscript. The AMS radiocarbon measurements were obtained by the "Laboratoire de mesures de C-14" LMC14 (UMS2572, CEA-CNRS-IRD-IRSN-Ministère de la Culture), Gif-sur-Yvette, France, through the IRD financial and technical support to this laboratory and the UCI Keck Carbon Cycle AMS Laboratory. We are grateful to the "FONDECYT" grant for the "Maestria en Ciencias del Mar that supported this research. We acknowledge support from the PALEOTRACES and PALEOPROXUS projects, and the Chaire croisée PROSUR, all partly supported by IRD. This work is a contribution of Sonderforschungsbereich 754 "ClimateBiogeochemistry interactions in the tropical ocean" (www.sfb754.de), which is supported by the Deutsche Forschungsgemeinschaft.

\section{REFERENCES}

Algeo, T.J., Tribovillard, N., 2009. Environmental analysis of paleoceanographic systems based on molybdenum-uranium covariation. Chemical Geology 268, 211-225.

Alves, S., Schiano, P., Capmas, F., Allègre, C.J., 2002. Osmium isotope binary mixing arrays in arc volcanism. Earth Planet. Sci. Lett. 198, 355-369. 
Anderson, R.F., Ali, S., Bradtmiller, L.I., Nielsen, S.H.H., Fleisher, M.Q., Anderson, B.E., Burckle, L.H., 2009. Wind-Driven Upwelling in the Southern Ocean and the Deglacial Rise in Atmospheric CO2. Science 323, 1443-1448.

Arthur, M.A., Dean, W.E., Laarkamp, K., 1998. Organic carbon accumulation and preservation in surface sediments on the Peru margin. Chemical Geology 152, 273-286.

Bakun, A., 1990. Global climate change and intensification of coastal upwelling. Science 247, 198-201.

Bakun, A., Weeks, S.J., 2008. The marine ecosystem off Peru: What are the secrets of its fishery productivity and what might its future hold? Progress in Oceanography 79, 290299.

Basak, C., Martin, E.E., Horikawa, K., Marchitto, T.M., 2010. Southern Ocean source of 14C-depleted carbon in the North Pacific Ocean during the last deglaciation. Nature geoscience 3, 770-773.

Behar, F., Beaumont, V., Penteado, H.L.D.B., 2001. Rock-Eval 6 technology: performances and developments. Oil \& Gas Science and Technology - Rev. IFP 56, 111-134.

Berger, A.L., 1978. A Simple algorithm to compute long term variations of Daily or monthly insolation Institut d'Astronomie et de Geophysique, Universite Catholique de Louvain, Louvain-la-Neuve, No. 18.

Böning, P., Brumsack, H.J., Bottcher, E., Schnetger, B., Kriete, C., Kallmeyer, J., Borchers, S.L., 2004. Geochemistry of Peruvian near-surface sediments. Geochimica et Cosmochimica Acta 68, 4429-4451.

Böning, P., Shaw, T., Pahnke, K., Brumsack, H.J., 2015. Nickel as indicator of fresh organic matter in upwelling sediments. Geochimica et Cosmochimica Acta 162, 99-108.

Brodie, I., Kemp, A.E.S., 1994. Variation in biogenic and detrital fluxes and formation of laminae in late Quaternary sediments from the Peruvian coastal upwelling zone. Marine Geology 116, 385-398.

Bruland, K.W., Rue, E.L., Smith, G.J., DiTullio, G.R., 2005. Iron, macronutrients and diatom blooms in the Peru upwelling regime: brown and blue waters of Peru. Marine Chemistry 93, 81-103.

Carré, M., Azzoug, M., Bentaleb, I., Chase, B.M., Fontugne, M., Jackson, D., Ledru, M.-P., Maldonado, A., Sachs, J.P., Schauer, A.J., 2012. Mid-Holocene mean climate in the south eastern Pacific and its influence on South America. Quat. Int. 253, 55-66. 
Chaigneau, A., Dominguez, N., Eldin, G., Vasquez, L., Flores, R., Grados, C., Echevin, V., 2013. Near-coastal circulation in the Northern Humboldt Current System from shipboard ADCP data. Journal of Geophysical Research 118.

Chase, Z., McManus, J., Mix, A.C., Muratli, J., 2014. Southern-ocean and glaciogenic nutrients control diatom export production on the Chile margin. Quaternary Science Reviews 99, 135-145.

Chazen, C.R., Altabet, M.A., Herbert, T.D., 2009. Abrupt mid-Holocene onset of centennialscale climate variability on the Peru-Chile Margin. Geophysical Research Letters 36, L18704.

Colodner, D.C., Boyle, E.A., Edmond, J.M., Thomson, J., 1992. Post-depositional mobility of platinum, iridium and rhenium in marine sediments. Nature 358, 402-404.

Colodner, D., Sachs, J., Ravizza, G., Turekian, K., Edmond, J., Boyle, E., 1993. The geochemical cycle of rhenium: a reconnaissance. Earth Planet. Sci. Lett. 117, 205-221.

Conroy, J.L., Overpeck, J.T., Cole, J.E., Shanahan, T.M., Steinitz-Kannan, M., 2008. Holocene changes in eastern tropical Pacific climate inferred from a Galapagos lake sediment record. Quaternary Science Reviews 27, 1166-1180.

Contreras, S., Lange, C.B., Pantoja, S., Lavik, G., Rincón-Martínez, D., Kuypers, M.M., 2010. A rainy northern Atacama Desert during the last interglacial. Geophysical Research Letters 37

Crusius, J., Calvert, S., Pedersen, T., Sage, D., 1996. Rhenium and molybdenum enrichments in sediments as indicators of oxic, suboxic and sulfidic conditions of deposition. Earth Planet. Sci. Lett. 145, 65-78.

Dean, W.E., Gardner, J.V., Anderson, R.Y., 1994. Geochemical evidence for enhanced preservation of organic matter in the oxygen minimum zone of the continental margin of northern California during the late Pleistocene. Paleoceanography 9, 47-61.

Dean, W.E., 2006. The geochemical record of the last 17,000 years in the Guaymas Basin, Gulf of California. Chemical Geology 232, 87-98.

Ehlert, C., Grasse, P., Gutierrez, D., Salvatteci, R., Frank, M., 2015. Nutrient utilisation and weathering inputs in the Peruvian upwelling region since the Little Ice Age. Climate of the Past 11, 187-202.

Falvey, M., Garreaud, R.D., 2009. Regional cooling in a warming world: Recent temperature trends in the southeast Pacific and along the west coast of subtropical South America (1979-2006). Journal of Geophysical Research 114, D04102. 
Fuenzalida, R., Schneider, W., Garces-Vargas, J., Bravo, L., Lange, C., 2009. Vertical and horizontal extension of the oxygen minimum zone in the eastern South Pacific Ocean. Deep-Sea Research II 56, 992-1003.

Furue, R., McCreary, J.P., Yu, Z., Wang, D., 2007. The dynamics of the southern Tsuchiya Jet. Journal of Physical Oceanography 37, 531-553.

Galbraith, E.D., Kienast, M., Pedersen, T.F., Calvert, S.E., 2004. Glacial-Interglacial modulation of the marine nitrogen cycle by high-latitude $\mathrm{O} 2$ supply to the global thermocline. Paleoceanography 19.

Galbraith, E.D., Kienast, M., and the NICOPP working group members, 2013. The acceleration of oceanic denitrification during deglacial warming. Nature geoscience. 6, $579-584$

Ganeshram, R.S., Pedersen, T.F., Calvert, S.E., McNeill, G.W., Fontugne, M.R., 2000. Glacial-interglacial variability in denitrification in the World's Oceans: Causes and consequences. Paleoceanography 15, 361-376.

Gilly, W.F., Beman, J.M., Litvin, S.Y., Robison, B.H., 2013. Oceanographic and biological effects of shoaling of the oxygen minimum zone. Annual Review of Marine Science 5, 393-420.

Glantz, S.A., 2002. Primer of Biostatistics, 5th ed. McGraw-Hill.

Gutierrez, D., Enriquez, E., Purca, S., Quipuzcoa, L., Marquina, R., Flores, G., Graco, M., 2008. Oxygenation episodes on the continental shelf of central Peru: Remote forcing and benthic ecosystem response. Progress in Oceanography 79, 177-189.

Gutierrez, D., Sifeddine, A., Field, D.B., Ortlieb, L., Vargas, G., Chavez, F., Velazco, F., Ferreira, V., Tapia, P., Salvatteci, R., Boucher, H., Morales, M.C., Valdes, J., Reyss, J.L., Campusano, A., Boussafir, M., Mandeng-Yogo, M., Garcia, M., Baumgartner, T., 2009. Rapid reorganization in ocean biogeochemistry off Peru towards the end of the Little Ice Age. Biogeosciences 6, 835-848.

Gutierrez, D., Bouloubassi, I., Sifeddine, A., Purca, S., Goubanova, K., Graco, M., Field, D., Méjanelle, L., Velazco, F., Lorre, A., Salvatteci, R., Quispe, D., Vargas, G., Dewitte, B., Ortlieb, L., 2011. Coastal cooling and increased productivity in the main upwelling zone off Peru since the mid-twentieth century. Geophysical Research Letters 38, L07603.

Helly, J., Levin, L., 2004. Global distribution of naturally occurring marine hypoxia on continental margin. Deep-Sea Research I 51, 1159-1168.

Helz, G.R., Miller, C.V., Charnock, J.M., Mosselmans, J.F.W., Patrick, R.A.D., Garner, C.D., Vaughan, D.J., 1996. Mechanism of molybdenum removal from the sea and its 
concentration in black shales: EXAFS evidence. Geochimica et Cosmochimica Acta 60, 3631-3642.

Helz, G.R., Adelson, J.M., 2013. Trace element profiles in sediments as proxies of dead zone history; rhenium compared to molybdenum. Environmental Science and Technology 47, $1257-1264$.

Helz, G.R., Dolor, M.K., 2012. What regulates rhenium deposition in euxinic basins? Chemical Geology 304-305, 131-141.

Hendy, I.L., Pedersen, T.F., 2006. Oxygen minimum zone expansion in the eastern tropical North Pacific during deglaciation. Geophysical Research Letters 33, L20602.

Higginson, M.J., Altabet, M.A., 2004. Initial test of the silicic acid leakage hypothesis using sedimentary biomarkers. Geophysical Research Letters 31, L18303.

Jaccard, S.L., Galbraith, E.D., 2012. Large climate-driven changes of oceanic oxygen concentrations during the last deglaciation. Nature geoscience 5, 151-156.

Jaccard, S.L., Gailbraith, E.D., Frölicher, T.L., Gruber, N., 2014. Ocean (de)oxygenation across the last deglaciation: Insights for the future. Oceanography 27, 26-35.

Jarvis, K.E., Gray, A.L., Houk, R.S., 1992. Handbook of Inductively Coupled Plasma Mass Spectrometry. Blackie Academic \& Professional, an imprint of Champan \& Hall, Wester Cleddens Road, Bishopgriggs, Glasgow, London Glasgow New York Tokyo Merlbourne Madras.

Jenny, B., Valero-Garcés, B.L., Villa-Martínez, R., Urrutia, R., Geyh, M., Veit, H., 2002. Early to Mid-Holocene Aridity in Central Chile and the Southern Westerlies: The Laguna Aculeo Record ( $\left.34^{\circ} \mathrm{S}\right)$. Quaternary Research 58, 160-170.

Karstensen, J., Ulloa, O., 2009. Peru-Chile current system, in: Steele, J.H., Thorpe, S.A., Turekian, K.K. (Eds.), Ocean currents, 2nd edition ed. Academic Press.

Karstensen, J., Stramma, L., Visbeck, M., 2008. Oxygen minimum zones in the eastern tropical Atlantic and Pacific oceans. Progress in Oceanography 77, 331-350.

Keeling, R.F., Körtzinger, A., Gruber, N., 2010. Ocean deoxygenation in a warming world. Annual Review of Marine Science 2, 199-229.

Koutavas, A., Demenocal, P.B., Olive, G.C., Lynch-Stieglitz, J., 2006. Mid-Holocene El Nino-Southern Oscillation (ENSO) attenuation revealed by individual foraminifera in eastern tropical Pacific sediments. Geology 34, 993-996.

Kuypers, M.M., Lavik, G., Woebken, D., Schmid, M., Fuchs, B.M., Amann, R., Jörgensen, B.B., Jetten, M.S.M., 2005. Massive nitrogen loss from the Benguela upwelling system through anaerobic ammonium oxidation. PNAS 102, 6478-6483. 
L'Heureux, M.L., Lee, S., Lyon, B., 2013. Recent multidecadal strengthening of theWalker circulation across the tropical Pacific. Nature climate change 3, 571-576.

Lafargue, E., Espitalié, J., Marquis, F., Pillot, D., 1998. Rock-Eval 6 applications in hydrocarbon exploration, production and in soil contaminations studies. Oil \& Gas Science and Technology - Rev. IFP 53, 421-437.

Lam, P., Lavik, G., Jensen, M., van de Vossenbergb, J., Schmid, M., Woebken, D., Gutierrez, D., Amann, R., Jetten, M., Kuypers, M.M., 2009. Revising the nitrogen cycle in the Peruvian oxygen minimum zone. PNAS 106, 4752-4757.

Lamy, F., Hebbeln, D., Röhl, U., Wefer, G., 2001. Holocene rainfall variability in southern Chile: a marine record of latitudinal shifts of the Southern Westerlies. Earth Planet. Sci. Lett. 185, 369-382.

Levin, L., Gutierrez, D., Rathburn, A., Neira, C., Sellanes, J., Muñoz, P., Gallardo, V., Salamanca, M., 2002. Benthic processes on the Peru margin: a transect across the oxygen minimum zone during the 1997-98 El Niño. Progress in Oceanography 53, 1-27.

Little, S.H., Vance, D., Lyons, T.W., McManus, J., 2015. Controls on trace metal authigenic enrichment in reducing sediments: insights from modern oxygen-deficient settings. American Journal of Science 315, 77-119.

Luo, J.-J., Sasaki, W., Masumoto, Y., 2012. Indian Ocean warming modulates Pacific climate change. PNAS 109, 18701-18706.

Makou, M.C., Eglinton, T.I., Oppo, D.W., Hughen, K.A., 2010. Postglacial changes in El Niño and La Niña behavior. Geology 38, 43-46.

Marchitto, T.M., Lehman, S.J., Ortiz, J., Fluck, J., Van Geen, A., 2007. Marine Radiocarbon Evidence for the Mechanism of Deglacial Atmospheric CO2 Rise. Science 316, 14561459.

Martinez, P., Lamy, F., Robinson, R.R., Pichevin, L., Billy, I., 2006. Atypical delta $\delta^{15} \mathrm{~N}$ variations at the southern boundary of the East Pacific oxygen minimum zone over the last 50 ka. Quaternary Science Reviews 25, 3017-3028.

Martinez, P., Robinson, R.S., 2010. Increase in water column denitrification during the last deglaciation: the influence of oxygen demand in the eastern equatorial Pacific. Biogeosciences 7, 1-9.

Migeon, S., Weber, O., Faugeres, J.-C., Saint-Paul, J., 1999. SCOPIX: A new X-ray imaging system for core analysis. Geo-Marine Letters 18, 251-255. 
Miller, C.A., Peucker-Ehrenbrink, B., Walker, B.D., Marcantonio, F., 2011. Re-assessing the surface cycling of molybdenum and rhenium. Geochimica et Cosmochimica Acta 75, 7146-7179.

Mollier-Vogel, E., Ryabenko, E., Martinez, P., Wallace, D., Altabet, M.A., Schneider, R., 2012. Nitrogen isotope gradients off Peru and Ecuador related to upwelling, productivity, nutrient uptake and oxygen deficiency. Deep-Sea Research I 70, 14-25.

Mollier-Vogel, E., Leduc, G., Böschen, T., Martinez, P., Schneider, R., 2013. Rainfall response to orbital and millennial forcing in northern Peru over the last $18 \mathrm{ka}$. Quaternary Science Reviews 76, 29-38.

Montes, I., Colas, F., Capet, X., Schneider, W., 2010. On the pathways of the equatorial subsurface currents in the eastern equatorial Pacific and their contributions to the PeruChile Undercurrent. Journal of Geophysical Research 115, C09003.

Moore, C.M., Mills, M.M., Arrigo, K.R., Berman-Frank, I., Bopp, L., Boyd, P.W., Galbraith, E.D., Geider, R.J., Guieu, C., Jaccard, S.L., Jickells, T.D., La Roche, J., Lenton, T.M., Mahowald, N.M., Marañón, E., Marinov, I., Moore, J.K., Nakatsuka, T., Oschlies, A., Saito, M.A., Thingstad, T.F., Tsuda, A., Ulloa, O., 2013. Processes and patterns of oceanic nutrient limitation. Nature geoscience 6, 701-710.

Morford, J.L., Emerson, S.R., Breckel, E.J., Kim, S.H., 2005. Diagenesis of oxyanions (V, U, $\mathrm{Re}$, and Mo) in pore waters and sediments from a continental margin. Geochimica et Cosmochimica Acta 69, 5021-5032.

Morford, J.L., Martin, W.R., Carney, C.M., 2009. Uranium diagenesis in sediments underlying bottom waters with high oxygen contents. Geochimica et Cosmochimica Acta 73, 2938-2960.

Morford, J.L., Martin, W.R., Carney, C.M., 2012. Rhenium geochemical cycling: Insights from continental margins. Chemical Geology 324-325, 73-86.

Moy, C.M., Seltzer, G.O., Rodbell, D.T., Anderson, D.M., 2002. Variability of El Niño/Southern Oscillation activity at millennial timescales during the Holocene epoch. Nature 420, 162-165.

Muratli, J., Chase, Z., Mix, A.C., McManus, J., 2010. Increased glacial-age ventilation of the Chilean margin by Antarctic Intermediate Water Nature geoscience 3, 23-26.

Nameroff, T.J., Balistrieri, L.S., Murray, J.W., 2002. Suboxic trace metal geochemistry in the eastern tropical North Pacific. Geochimica et Cosmochimica Acta 66, 1139-1158. 
Nameroff, T.J., Calvert, S.E., Murray, J.W., 2004. Glacial-interglacial variability in the eastern tropical North Pacific oxygen minimum zone recorded by redox-sensitive trace metals. Paleoceanography 19, PA1010.

Pennington, J.T., Mahoney, K.L., Kuwahara, V.S., Kolber, D.D., Calienes, R., Chavez, F.P., 2006. Primary production in the eastern tropical Pacific: A review. Progress in Oceanography 69, 285-317.

Peters, K.E., Walters, C.C., Moldowan, J.M., 2005. The Biomarker Guide. Cambridge University Press.

Rafter, P.A., Sigman, D.M., Charles, C.D., Kaiser, J., Haug, G.H., 2012. Subsurface tropical Pacific nitrogen isotopic composition of nitrate: Biogeochemical signals and their transport. Global and Biogeochemical Cycles 26, GB1003.

Rein, B., Lückge, A., Reinhardt, L., Sirocko, F., Wolfe, A., Dullo, W.-C., 2005. El Niño variability off Peru during the last 20,000 years. Paleoceanography 20, PA4003.

Reinhardt, L., Kudrasss, H.-R., Lückge, A., Wiedicke, M., Wunderlich, J., Wendt, G., 2002. High-resolution sediment echosounding off Peru: Late Quaternary depositional sequences and sedimentary structures of a current-dominated shelf Marine Geophysical Researches $23,335-351$.

Robinson, R.S., Mix, A., Martinez, P., 2007. Southern Ocean control on the extent of denitrification in the southeast Pacific over the last $70 \mathrm{ka}$. Quaternary Science Reviews 2007, 201-212.

Robinson, R.S., Martinez, P., Pena, L.D., Cacho, I., 2009. Nitrogen isotopic evidence for deglacial changes in nutrient supply in the eastern equatorial Pacific. Paleoceanography 24, PA4213.

Salvatteci, R., Field, D.B., Baumgartner, T., Ferreira, V., Gutierrez, D., 2012. Evaluating fish scale preservation in sediment records from the oxygen minimum zone off Peru. Paleobiology 38, 52-78.

Salvatteci, R., Field, D., Sifeddine, A., Ortlieb, L., Ferreira, V., Baumgartner, T., Caquineau, S., Velazco, F., Reyss, J.L., Sanchez-Cabeza, J.A., Gutierrez, D., 2014a. Crossstratigraphies from a seismically active mud lens off Peru indicate horizontal extensions of laminae, missing sequences, and a need for multiple cores for high resolution records. Marine Geology 357, 72-89.

Salvatteci, R., Gutierrez, D., Field, D., Sifeddine, A., Ortlieb, L., Bouloubassi, I., Boussafir, M., Boucher, H., Cetin, F., 2014b. The response of the Peruvian Upwelling Ecosystem to 

731.

Sanchez, G., Calienes, R., Zuta, S., 2000. The 1997-98 El Niño and its effects on the coastal marine ecosystem off Peru. CalCOFI Rep. 41, 62-86.

Sarbas, B., Nohl, U., 2009. The GEOROC database - a decade of "online geochemistry". Geochimica et Cosmochimica Acta 73.

Savrda, C.E., Bottjer, D.J., 1991. Oxygen-related biofacies in marine strata: an overview and update, in: Tyson, R.V., Pearson, T.H. (Eds.), Modern and ancient continental shelf anoxia. Geol. Soc. London Spec. Publ., London, pp. 201-219.

Schmidtko, S., Johnson, G.C., 2012. Multidecadal Warming and Shoaling of Antarctic Intermediate Water. Journal of Climate 25, 207-221.

Scholz, F., Hensen, C., Noffke, A., Rohde, A., Liebetrau, V., Wallmann, K., 2011. Early diagenesis of redox-sensitive trace metals in the Peru upwelling area - response to ENSO-related oxygen fluctuations in the water column. Geochimica et Cosmochimica Acta 75, 7257-7276.

Scholz, F., McManus, J., Sommer, S., 2013. The manganese and iron shuttle in a modern euxinic basin and implications for molybdenum cycling at euxinic ocean margins. Chemical Geology 355, 56-68.

Scholz, F., McManus, J., Mix, A., Hensen, C., Schneider, R., 2014. The impact of ocean deoxygenation on the ocean's iron supply. Nature Geoscience 7, 433-437.

Schönfeld, J., Kuhnt, W., Erdem, Z., Flögel, S., Glock, N., Aquit, M., Frank, M., Holbourn, A., 2015. Records of past mid-depth ventilation: Cretaceous ocean anoxic event 2 vs. recent oxygen minimum zones. Biogeosciences 12, 1169-1189.

Skilbeck, C.G., Fink, D., 2006. Data report: Radiocarbon dating and sedimentation rates for Holocene-upper Pleistocene sediments, eastern equatorial Pacific and Peru continental margin, in: Jorgensen, B.B., D'Hondt, S.L., Miller, D.J. (Eds.), Proc. ODP, Sci. Results, $201,1-15$.

Stramma, L., Johnson, G.C., Sprintall, J., Mohrholz, V., 2008. Expanding Oxygen-Minimum Zones in the Tropical Oceans. Science 320, 655-658.

Stramma, L., Johnson, G.C., Firing, E., Schmidtko, S., 2010a. Eastern Pacific oxygen minimum zones: Supply paths and multidecadal changes. Journal of Geophysical Research 115.

Stramma, L., Schmidtko, S., Levin, L.A., Johnson, G.C., 2010b. Ocean oxygen minima expansions and their biological impacts. Deep-Sea Research I 57, 587-595. 
Sundby, B., Martinez, P., Gobeil, C., 2004. Comparative geochemistry of cadmium, rhenium, uranium, and molybdenum in continental margin sediments. Geochimica et Cosmochimica Acta 68, 2485-2493.

Tribovillard, N., Algeo, T.J., Lyons, T., Riboulleau, A., 2006. Trace metals as paleoredox and paleoproductivity proxies: An update. Chemical Geology 232, 12-32.

Van der Weijden, C.H., 2002. Pitfalls of normalization of marine geochemical data using a common divisor. Marine Geology 184, 167-187.

van Geen, A., Fairbanks, R.G., Dartnell, P., McGann, M., Gardner, J.V., Kashgarian, M., 1996. Ventilation changes in the northeast Pacific during the last deglaciation. Paleoceanography 11, 519-528.

Vargas, G., Pantoja, S., Rutlant, J.A., Lange, C., Ortlieb, L., 2007. Enhancement of coastal upwelling and interdecadal ENSO-like variability in the Peru-Chile Current since late 19th century. Geophysical Research Letters 34, L13607.

Varma, V., Prange, M., Lamy, F., Merkel, U., Schulz, M., 2011. Solar-forced shifts of the Southern HemisphereWesterlies during the Holocene. Climate of the Past 7, 339-347.

Waser, N.A.D., Harrison, P.J., Nielsen, B., Calvert, S.E., Turpin, D.H., 1998. Nitrogen isotope fractionation during the uptake and assimilation of nitrate, nitrite, ammonium, and urea by a marine diatom. Limnology and Oceanography 43, 215-224.

Zehr, J.P., 2009. New twist on nitrogen cycling in oceanic oxygen minimum zones. PNAS $106,4575-4576$.

Zheng, Y., Anderson, R.F., Van Geen, A., Kuwabara, J., 2000. Authigenic molybdenium formation in marine sediments: a link to pore water sulfide in the Santa Barbara Basin. Geochimica et Cosmochimica Acta 64, 4165-4178.

Zheng, Y., Anderson, R.F., van Geen, A., Fleisher, M.Q., 2002. Preservation of nonlithogenic particulate uranium in marine sediments. Geochimica et Cosmochimica Acta 66 ,

3085-3092. 
Centennial to millennial-scale changes in oxygenation and productivity in the Eastern Tropical South Pacific during the last 25000 years

R. Salvatteci ${ }^{1,2^{*}}$; D. Gutierrez ${ }^{3,4}$; A. Sifeddine ${ }^{1,5}$; L. Ortlieb ${ }^{1}$, E. Druffel ${ }^{6}$; M. Boussafir ${ }^{7}$; R. Schneider ${ }^{2}$

\section{Tables}

Table 1. Average and standard deviation of the proxies developed in the composite record separated by time intervals of interest. The current warm period comprises the last 100 years.

\begin{tabular}{|c|c|c|c|c|c|c|c|c|c|c|c|c|c|c|c|c|c|c|c|c|c|c|c|c|}
\hline \multirow[b]{2}{*}{ TOC (\%) } & \multirow{2}{*}{$\begin{array}{l}\begin{array}{l}\text { Current } \\
\text { period }\end{array} \\
6.6\end{array}$} & \multirow{2}{*}{\multicolumn{2}{|c|}{$\begin{array}{c}\text { Warm } \\
\pm \quad 1.7\end{array}$}} & \multicolumn{3}{|c|}{ Late Holocene } & \multicolumn{3}{|c|}{ Mid-Holocene } & \multicolumn{3}{|c|}{$\begin{array}{l}\text { Early } \\
\text { Holocene }\end{array}$} & \multicolumn{2}{|c|}{$\begin{array}{l}\text { Antarctic } \\
\text { reversal }\end{array}$} & \multirow{2}{*}{$\begin{array}{c}\text { cold } \\
0.7\end{array}$} & \multicolumn{2}{|c|}{$\begin{array}{l}\text { Heinrich } \\
\text { Stadial }\end{array}$} & 1 & \multicolumn{3}{|c|}{$\begin{array}{l}\text { Last } \\
\text { Maximum }\end{array}$} & \multicolumn{3}{|c|}{ Early glacial } \\
\hline & & & & 5.8 & \pm & 0.9 & 5.3 & \pm & 1.1 & 4.5 & \pm & 0.6 & 3.7 & \pm & & 3.0 & \pm & 0.4 & 2.2 & \pm & 0.4 & 2.2 & \pm & 0.5 \\
\hline TOC/Al & 3.1 & \pm & 0.36 & 1.4 & \pm & 0.49 & 1.2 & \pm & 0.36 & 0.9 & \pm & 0.19 & 0.6 & \pm & 0.12 & 0.6 & \pm & 0.15 & 0.4 & \pm & 0.1 & 0.3 & \pm & 0.1 \\
\hline HI (mg.HC.g-1 TOC) & 472 & \pm & 17 & 427 & \pm & 34 & 428 & \pm & 26 & 427 & \pm & 25 & 400 & \pm & 31 & 400 & \pm & 38 & 305 & \pm & 21 & 300 & \pm & 28 \\
\hline$\delta^{15} \mathrm{~N}(\%)$ & 8.4 & \pm & 0.9 & 6.4 & \pm & 1.0 & 5.8 & \pm & 0.7 & 7.2 & \pm & 0.8 & 9.2 & \pm & 0.9 & 9.3 & \pm & 1.2 & 5.2 & \pm & 0.4 & 5.0 & \pm & 0.8 \\
\hline $\mathrm{Al}(\%)$ & 2.1 & \pm & 0.8 & 4.5 & \pm & 1.2 & 4.6 & \pm & 1.2 & 4.9 & \pm & 1.0 & 6.4 & \pm & 0.3 & 5.5 & \pm & 1.0 & 5.9 & \pm & 0.5 & 6.4 & \pm & 0.6 \\
\hline Nixs (mg/kg) & 47.0 & \pm & 9.6 & 60.6 & \pm & 16.2 & 57.3 & \pm & 10.6 & 57.3 & \pm & 9.8 & 41.4 & \pm & 13.3 & 28.9 & \pm & 5.6 & 19.8 & \pm & 9.0 & 12.5 & \pm & 8.3 \\
\hline Cuxs (mg/kg) & 26.5 & \pm & 10.2 & 24.7 & \pm & 6.3 & 25.1 & \pm & 3.3 & 23.8 & \pm & 4.8 & 13.0 & \pm & 4.4 & 12.9 & \pm & 5.0 & 11.5 & \pm & 5.3 & 8.2 & \pm & 6.1 \\
\hline Moxs (mg/kg) & 74.8 & \pm & 4.3 & 43.5 & \pm & 19.7 & 34.6 & \pm & 5.8 & 45.8 & \pm & 11.6 & 16.8 & \pm & 4.1 & 21.4 & \pm & 7.3 & 15.1 & \pm & 5.4 & 21.8 & \pm & 8.6 \\
\hline Uxs (mg/kg) & nd & \pm & nd & 11.1 & \pm & 3.6 & 10.9 & \pm & 2.2 & 9.7 & \pm & 2.3 & 8.8 & \pm & 2.5 & 5.0 & \pm & 1.7 & 6.8 & \pm & 1.3 & 8.3 & \pm & 1.8 \\
\hline Rexs (ug/Kg) & 24.7 & \pm & 7.4 & 39.2 & \pm & 10.4 & 40.6 & \pm & 9.9 & 36.5 & \pm & 8.7 & 28.8 & \pm & 5.7 & 19.2 & \pm & 3.7 & 21.0 & \pm & 3.9 & 21.8 & \pm & 4.0 \\
\hline Mo/U & nd & \pm & nd & 4.3 & \pm & 2.0 & 3.3 & \pm & 0.7 & 5.0 & \pm & 1.8 & 2.0 & \pm & 0.3 & 4.5 & \pm & 1.5 & 2.2 & \pm & 0.6 & 2.7 & \pm & 1.2 \\
\hline $\mathrm{Re} / \mathrm{Mo}$ & 0.3 & \pm & 0.1 & 1.1 & \pm & 0.5 & 1.2 & \pm & 0.3 & 0.9 & \pm & 0.3 & 1.7 & \pm & 0.2 & 1.0 & \pm & 0.3 & 1.5 & \pm & 0.3 & 1.1 & \pm & 0.3 \\
\hline EF Ni & 8.9 & \pm & 1.1 & 5.9 & \pm & 2.8 & 5.2 & \pm & 1.4 & 4.7 & \pm & 1.0 & 2.6 & \pm & 0.9 & 2.2 & \pm & 0.6 & 1.3 & \pm & 0.6 & 0.8 & \pm & 0.6 \\
\hline $\mathrm{EF} \mathrm{Cu}$ & 2.8 & \pm & 0.5 & 1.4 & \pm & 0.7 & 1.4 & \pm & 0.6 & 1.2 & \pm & 0.4 & 0.5 & \pm & 0.2 & 0.6 & \pm & 0.3 & 0.5 & \pm & 0.3 & 0.3 & \pm & 0.2 \\
\hline EF Mo & 151.4 & \pm & 47.8 & 45.4 & \pm & 33.3 & 33.5 & \pm & 16.7 & 40.3 & \pm & 18.5 & 10.4 & \pm & 3.0 & 16.6 & \pm & 8.6 & 10.4 & \pm & 5.0 & 14.1 & \pm & 7.0 \\
\hline EF U & nd & \pm & nd & 8.0 & \pm & 4.0 & 7.6 & \pm & 3.0 & 6.0 & \pm & 1.8 & 4.0 & \pm & 1.2 & 2.8 & \pm & 1.1 & 3.4 & \pm & 0.9 & 3.9 & \pm & 1.0 \\
\hline EF Re & 614 & \pm & 113 & 478 & \pm & 153 & 477 & \pm & 114 & 391 & \pm & 68 & 234 & \pm & 57 & 186 & \pm & 40 & 187 & \pm & 49 & 180 & \pm & 42 \\
\hline
\end{tabular}


Table 2. Pearson coefficient correlation matrix for total organic carbon, $\delta^{15} \mathrm{~N}$, authigenic metals in the composite record B14-G10-G14. The asterisks replace values derived from two categories that share the same data (e.g. $\mathrm{Re}_{\mathrm{xs}}$ and $\mathrm{Re} / \mathrm{Mo}$ ). The probability level was corrected for multiple comparisons by dividing the probability level $\alpha(\mathrm{p}<0.05$ ) by the number of tests (10) performed (Glantz 2002). Boldface indicate significant values after correcting for multiple comparisons ( $p<0.005)$.

\begin{tabular}{|c|c|c|c|c|c|c|c|c|c|c|c|}
\hline & $\begin{array}{l}\text { TOC } \\
\text { (\%) }\end{array}$ & $\begin{array}{l}\text { HI } \\
\text { (mg.HC.g- } \\
1 \text { TOC) }\end{array}$ & $\begin{array}{l}\delta^{15} \mathrm{~N} \\
(\% \circ)\end{array}$ & $\begin{array}{l}\text { Al } \\
(\%)\end{array}$ & $\begin{array}{l}\text { Nixs } \\
(\mathrm{mg} / \mathrm{kg})\end{array}$ & $\begin{array}{l}\text { Cuxs } \\
(\mathrm{mg} / \mathrm{kg})\end{array}$ & $\begin{array}{l}\text { Moxs } \\
(\mathrm{mg} / \mathrm{kg})\end{array}$ & $\begin{array}{l}\text { Uxs } \\
(\mathrm{mg} / \mathrm{kg})\end{array}$ & $\begin{array}{l}\text { Rexs } \\
\text { (ug/Kg) }\end{array}$ & Mo/U & $\mathrm{Re} / \mathrm{Mo}$ \\
\hline TOC (\%) & 1 & & & & & & & & & & \\
\hline $\begin{array}{l}\text { HI (mg.HC.g-1 } \\
\text { TOC) }\end{array}$ & 0.68 & 1 & & & & & & & & & \\
\hline$\delta^{15} \mathrm{~N}(\%)$ & -0.23 & 0.37 & 1 & & & & & & & & \\
\hline $\mathrm{Al}(\%)$ & -0.40 & -0.63 & -0.15 & 1 & & & & & & & \\
\hline Nixs (mg/kg) & 0.90 & 0.71 & -0.14 & -0.43 & 1 & & & & & & \\
\hline Cuxs (mg/kg) & 0.84 & 0.67 & -0.24 & -0.56 & 0.83 & 1 & & & & & \\
\hline Moxs (mg/kg) & 0.62 & 0.57 & 0.03 & -0.60 & 0.67 & 0.69 & 1 & & & & \\
\hline Uxs (mg/kg) & 0.71 & 0.35 & -0.45 & -0.25 & 0.65 & 0.65 & 0.54 & 1 & & & \\
\hline Rexs (ug/Kg) & 0.87 & 0.46 & -0.44 & -0.15 & 0.82 & 0.74 & 0.54 & 0.78 & 1 & & \\
\hline $\mathrm{Mo} / \mathrm{U}$ & 0.08 & 0.41 & 0.43 & -0.46 & 0.17 & 0.21 & * & * & -0.10 & 1 & \\
\hline $\mathrm{Re} / \mathrm{Mo}$ & 0.01 & -0.31 & -0.35 & 0.54 & -0.06 & -0.21 & * & 0.03 & * & * & 1 \\
\hline
\end{tabular}


Table 3. Pearson coefficient correlation matrix for normalized total organic carbon, $\mathrm{HI}, \delta^{15} \mathrm{~N}$, and enrichment factors in the composite record B14-G10-G14. Correlations were calculated only in samples where all the proxies were measured $(n=264$; see Table SM2). The asterisks replace values derived from two categories that share the same data (e.g. $\mathrm{EF} \mathrm{Re}_{\text {auth }}$ and $\mathrm{Re} / \mathrm{Mo}$ ). The probability level was corrected for multiple comparisons by dividing the probability level $\alpha(\mathrm{p}<0.05)$ by the number of tests $(9)$ performed (Glantz 2002). Boldface indicate significant values after correcting for multiple comparisons $(p<0.0056)$.

\begin{tabular}{|c|c|c|c|c|c|c|c|c|c|c|}
\hline & TOC/Al & $\begin{array}{l}\text { HI } \\
\text { (mg.HC.g- } \\
1 \text { TOC) }\end{array}$ & $\delta^{15} \mathrm{~N}(\%)$ & $\mathrm{EF} \mathrm{Ni}$ & $\mathrm{EF} \mathrm{Cu}$ & EF Mo & EF U & EF Re & Mo/U & Re/Mo \\
\hline TOC/Al & 1 & & & & & & & & & \\
\hline $\begin{array}{l}\text { HI (mg.HC.g-1 } \\
\text { TOC) }\end{array}$ & 0.69 & 1 & & & & & & & & \\
\hline$\delta^{15} \mathbf{N}(\%)$ & -0.06 & 0.37 & 1 & & & & & & & \\
\hline EF Ni & 0.94 & 0.71 & -0.03 & 1 & & & & & & \\
\hline EF Cu & 0.93 & 0.64 & -0.06 & 0.90 & 1 & & & & & \\
\hline EF Mo & 0.81 & 0.54 & 0.08 & 0.83 & 0.85 & 1 & & & & \\
\hline EF U & 0.86 & 0.50 & -0.18 & 0.80 & 0.84 & 0.77 & 1 & & & \\
\hline EF Re & 0.91 & 0.64 & -0.25 & 0.89 & 0.84 & 0.71 & 0.83 & 1 & & \\
\hline $\mathrm{Mo} / \mathrm{U}$ & 0.27 & 0.41 & 0.43 & 0.33 & 0.33 & $*$ & $*$ & 0.14 & 1 & \\
\hline Re/Mo & -0.29 & -0.31 & -0.35 & -0.31 & -0.40 & $*$ & -0.27 & $*$ & $*$ & 1 \\
\hline
\end{tabular}


Pacific during the last 25000 years

R. Salvatteci ${ }^{1,2^{*}}$; D. Gutierrez ${ }^{3,4}$; A. Sifeddine ${ }^{1,5}$;L. Ortlieb ${ }^{1}$, E. Druffel ${ }^{6} ;$ M. Boussafir $^{7}$; R. Schneider ${ }^{2}$

${ }^{1}$ IRD-Sorbonne Universités (UPMC, Univ. Paris 06)-CNRS-MNHN, LOCEAN Laboratory, Center IRD France-Nord,

32, Avenue Henri Varagnat, F-93143 Bondy, France

${ }^{2}$ Institute of Geoscience, Department of Geology, Kiel University, Ludewig-Meyn-Str. 10, 24118 Kiel, Germany

${ }^{3}$ Instituto del Mar del Perú, Esquina Gamarra y General Valle s/n, Callao 22000, Peru

${ }^{4}$ Programa Maestría en Ciencias del Mar, Universidad Peruana Cayetano Heredia, Lima, Peru

${ }^{5}$ Departamento de Geoquimica, Universidade Federal Fluminense, Niteroi, Brazil

${ }^{6}$ Department of Earth System Science, University of California - Irvine, California, USA

${ }^{7}$ Institut des Sciences de la Terre d'Orléans, UMR7327 - INSU/CNRS/BRGM/Université d'Orléans, 1A rue de la férollerie, 45701 Orléans CEDEX-2, France

* Corresponding author. E-mail address: renatosalvatteci@gmail.com

\section{FIGURES}
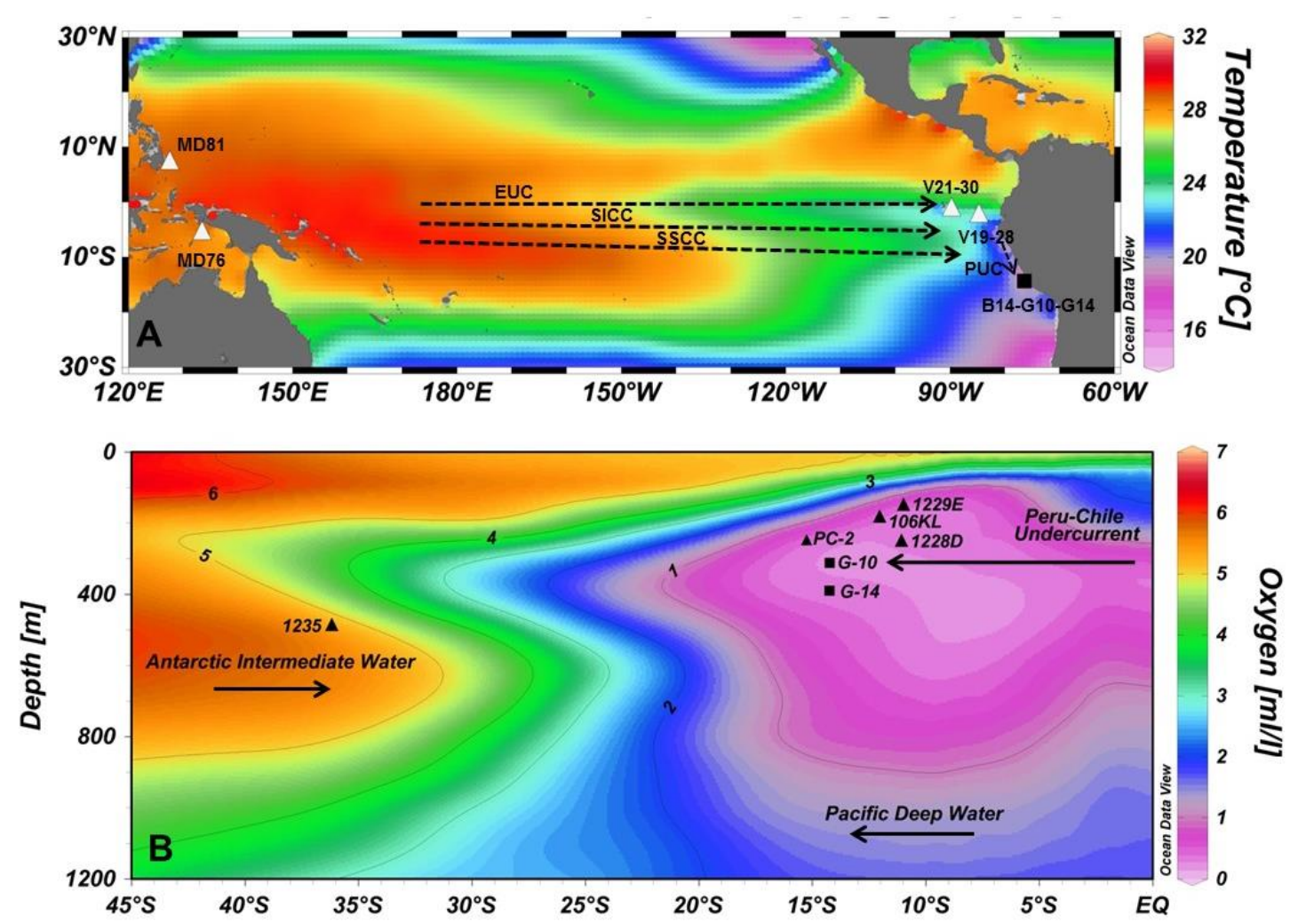

Figure 1. A) Sea surface temperature plot over the Tropical Pacific showing locations of cores (B14, G10, G14) used in this study (black square) and cores from other studies (white triangles V21-30 and V19-28 (Koutavas et al.; 2006); MD76 and MD81 (Stott et al., 2004). Cores V21-30, V19-28, MD76 and MD81 were used by Koutavas et al., (2006) to infer the SST gradient across the Tropical Pacific during the Holocene. Discontinuous lines indicate the main tropical undercurrents: Equatorial undercurrent (EUC), South Intermediate current (SICC) and Southern subsurface countercurrents (SSCC) and the Peru-Chile Undercurrent (PUC). B) Dissolved oxygen content in a meridional transect along $85^{\circ} \mathrm{W}$, showing the principal water masses and the position of the cores. Black squares are our cores (G10 and G14), black triangles are cores of published data we discuss in the present study: ODP site 1235 (Muratli et al., 2010 ); PC-2 (Chazen et al., 2009); ODP 1229E (Contreras et al., 2010); ODP 1228D (Makou et al., 2010); 106KL (Rein et al., 2005). 


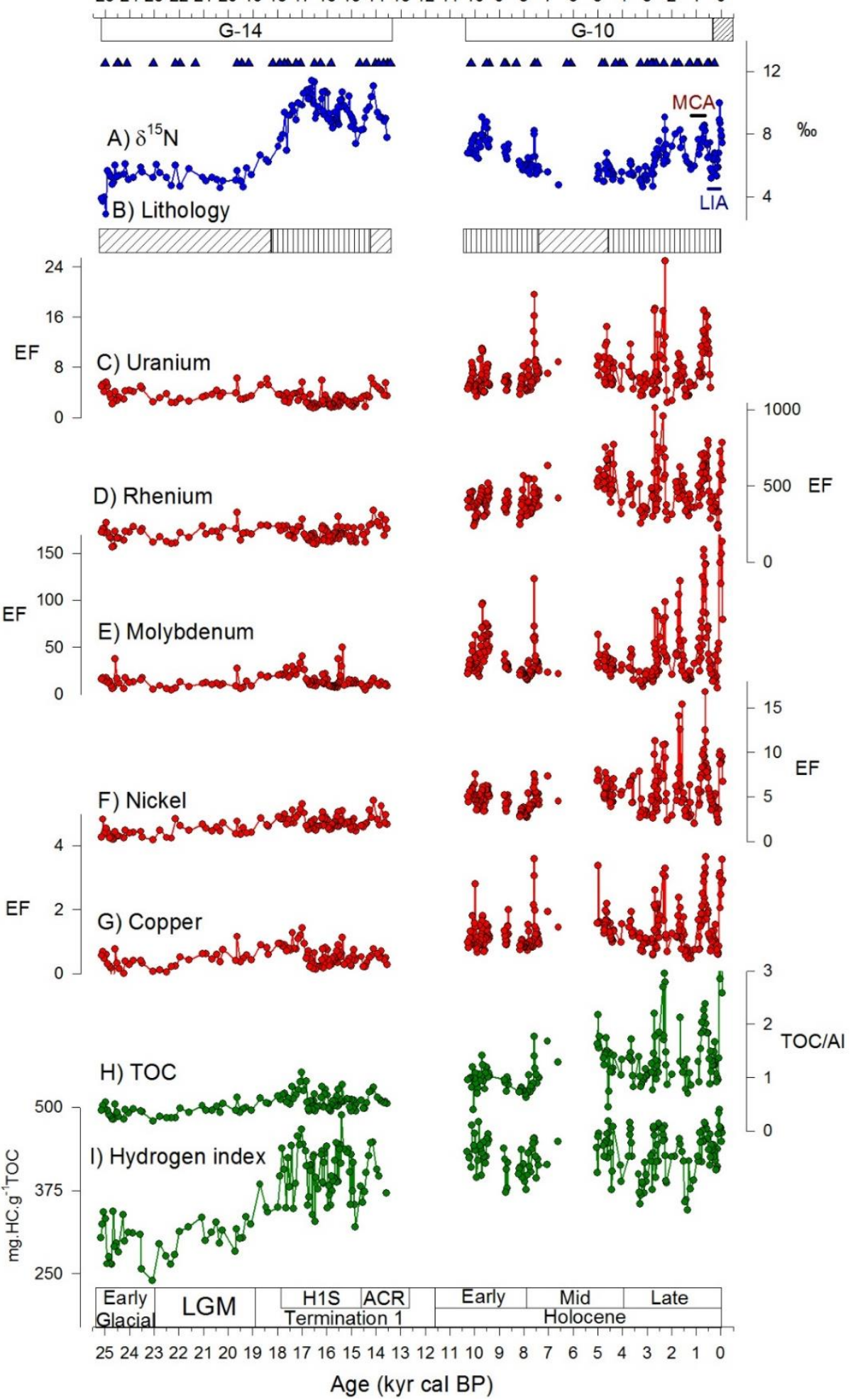

Figure 2. Stacked record assembled using cores B14, G10 and G14 showing proxies for water column denitrification, benthic redox conditions and export production during the last $25 \mathrm{kyr}$ BP. A) $\delta^{15} \mathrm{~N}$ as a proxy for water column denitrification, the blue triangles indicate the position of the ${ }^{14} \mathrm{C}$ ages. B) Simplified lithology of the core showing predominantly laminated sequences (vertical stripes) and banded sequences (diagonal stripes); see supplementary material for a detailed description. C) Authigenic Uranium enrichment factor (EF). D) Authigenic Rhenium EF. E) Authigenic Molybdenum EF. F) Authigenic Nickel EF. G) Authigenic Copper EF. H) Total organic carbon (TOC) normalized to Al. I) Hydrogen index as a proxy for organic matter preservation (mg.HC. ${ }^{-1}$ TOC). The acronyms used in this figure as follow: Last Glacial Maximum (LGM), Heinrich 1 Stadial (H1S), Antarctic Cold Reversal (ACR), Current Warm period (CWP). The boxes on top indicate the extent of each sediment core, the finely vertically striped box indicate the extent of core B-14. 


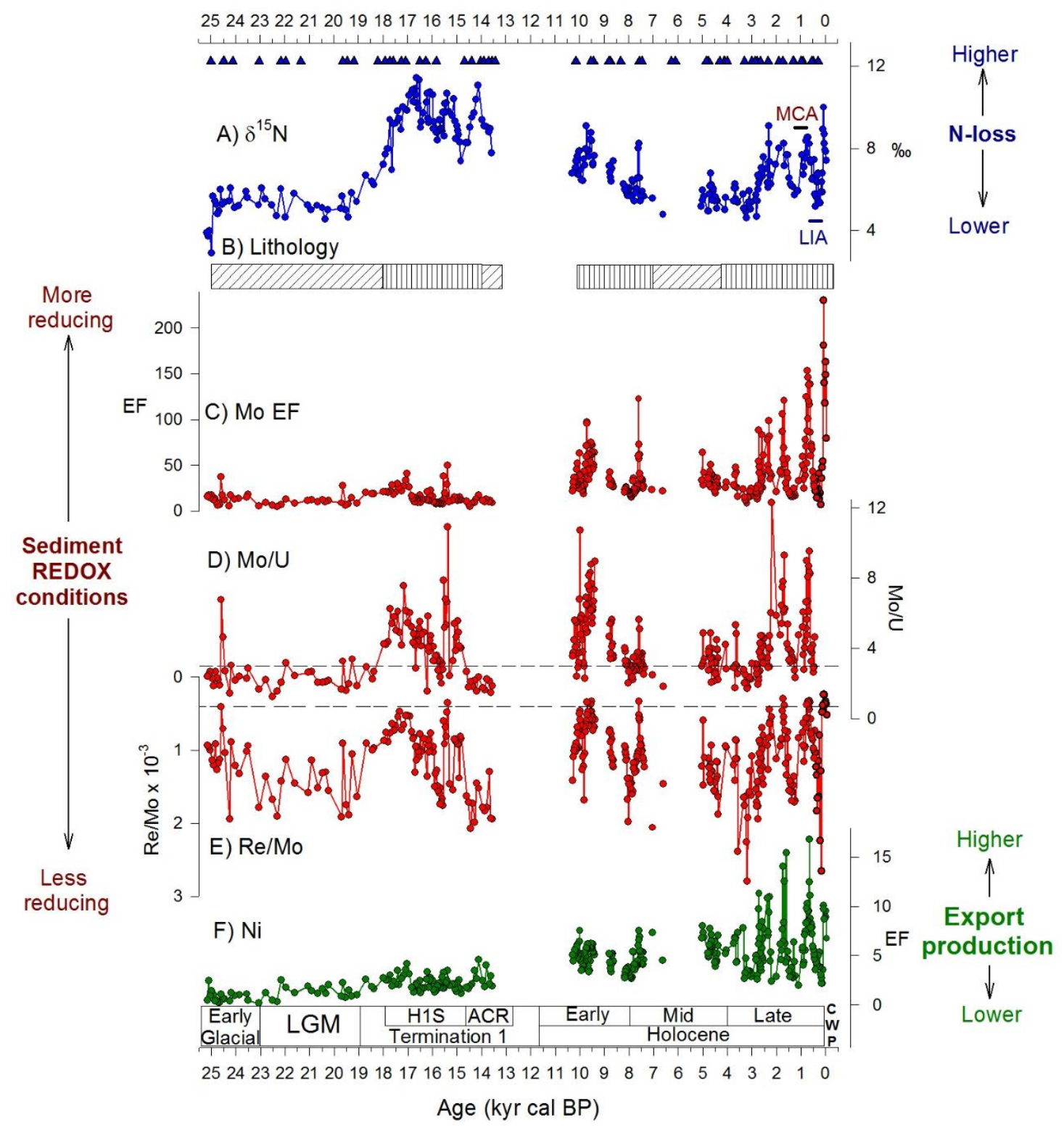

Figure 3. Stacked record assembled using cores B14, G10 and G14 showing proxies for water column denitrification, benthic redox conditions and export production during the last $25 \mathrm{kyr}$. A) $\delta^{15} \mathrm{~N}$ as a proxy for water column denitrification. B) Simplified lithology of the core showing predominantly laminated sequences (vertical stripes) and banded sequences (diagonal stripes); blue triangles indicate the position of the ${ }^{14} \mathrm{C}$ ages, see supplementary material for a detailed description. C) Molybdenum authigenic enrichment factor (EF) as proxy for benthic oxygenation. D) Authigenic Mo/U ratio as a proxy to infer anoxic from suboxic conditions. The discontinuous line indicate the value of 3.2 which correspond the Mo/U weight ratio in seawater, higher values than 3.2 indicate sulfidic conditions. E) Authigenic Re/Mo ratio ( $y$-axis inverted), the horizontal dashed line indicates the value of $0.4 \times 10^{-3}$ which corresponds to the ratio of the concentration of these metals in the sea-water (Crusius et al., 1996); values higher (equal or lower) than $0.4 \times 10^{-3}$ indicate suboxic (sulfidic) conditions. F) Nickel EF as a proxy for export production. The acronyms listed as in Figure 2. 


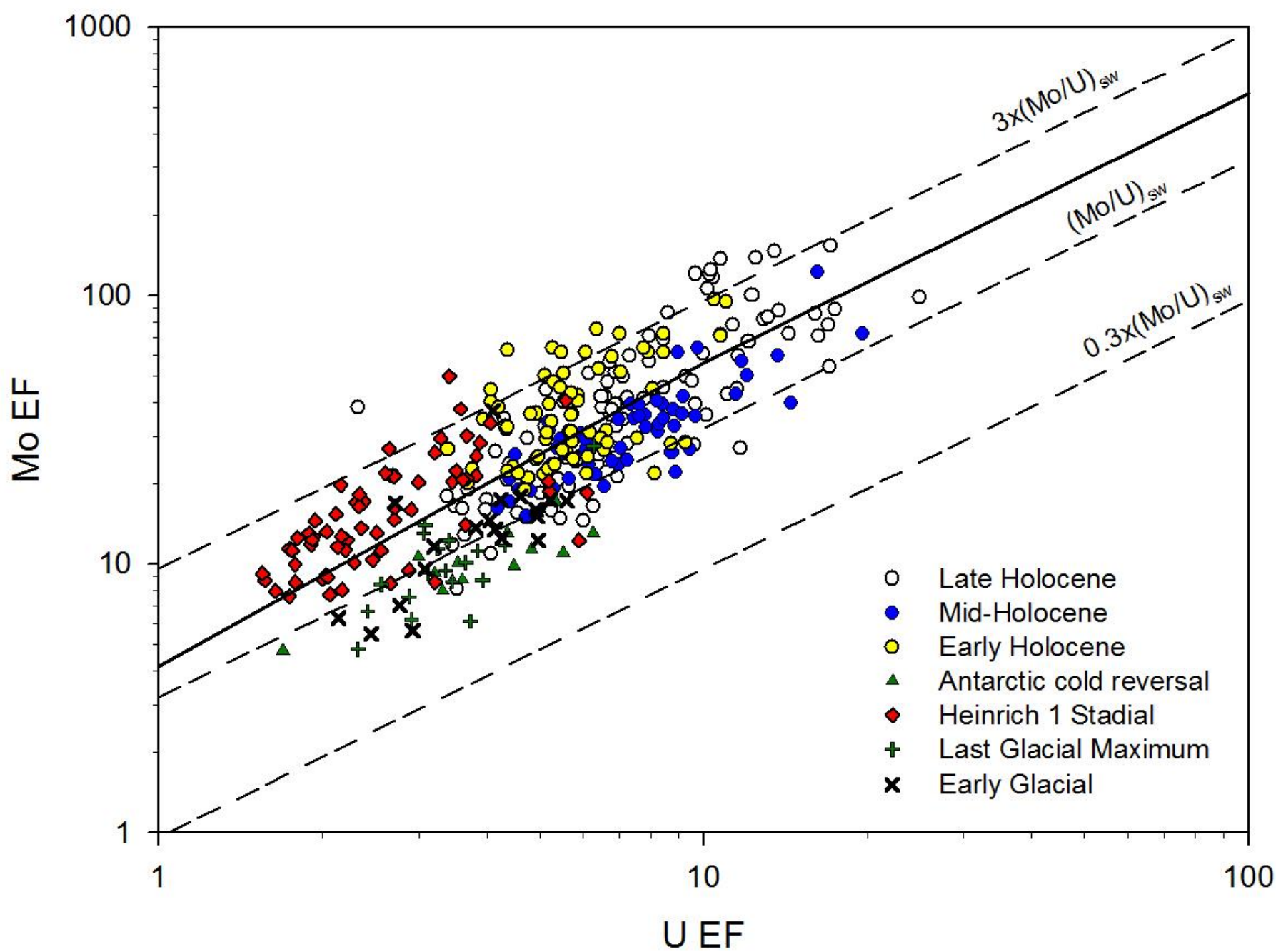

Figure 4. Cross plot of Mo enrichment factors versus $U$ enrichment factors. The dashed lines indicate the relative proportion of $\mathrm{Mo}$ and $\mathrm{U}$ in seawater (weight ratio of $[\mathrm{Mo}]_{s w} /[\mathrm{U}]_{s w}=3.2$ ) and to fractions thereof $(0.3 \mathrm{x}$ and $3 \mathrm{x})$. The solid line represents the linear regression of all the data set $\left(r^{2}=0.58 ; n=342\right)$. The symbols indicate the different samples from the different periods of interest. Note the logarithmic scale of both axes. 


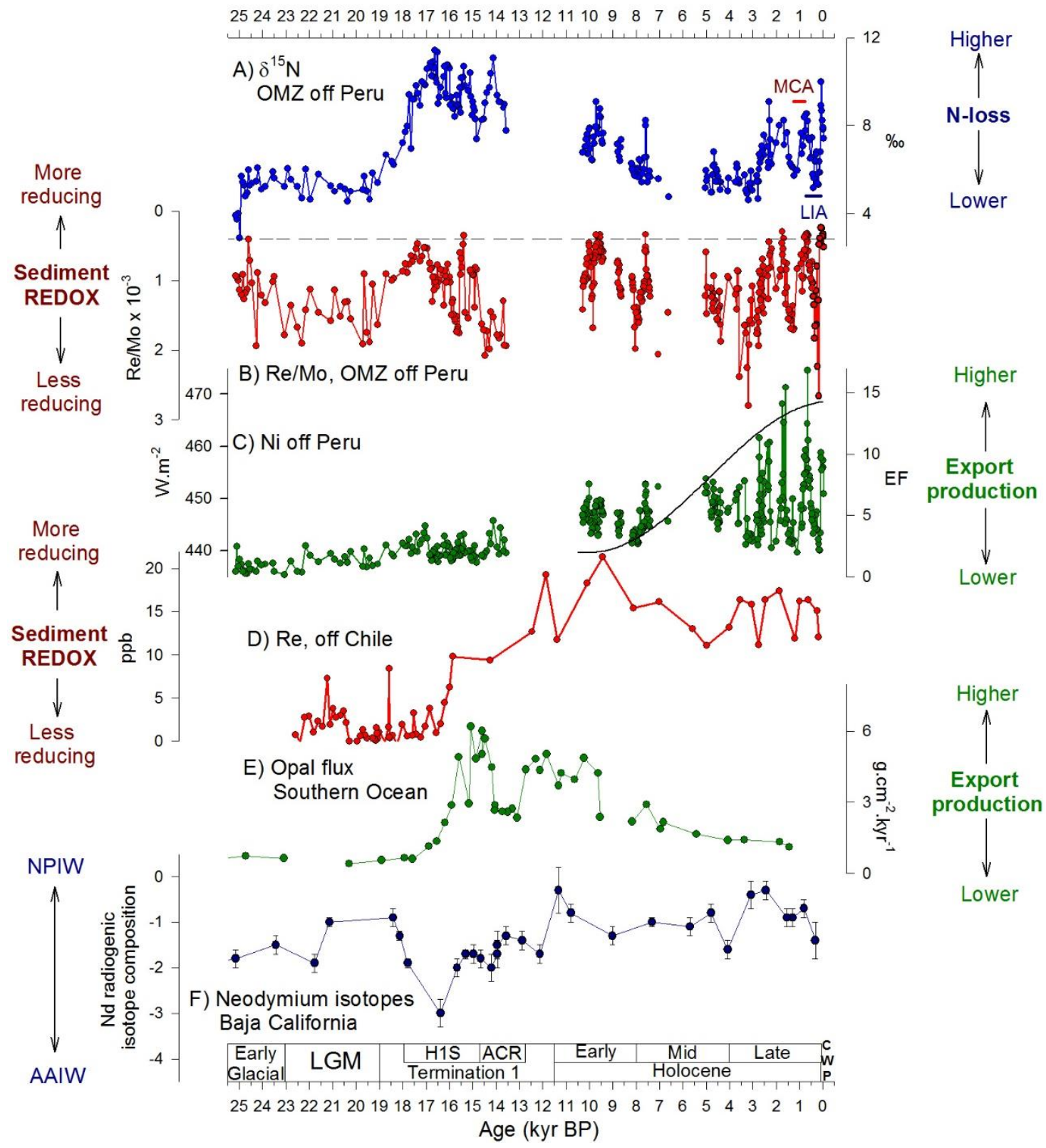

Figure 5. Comparison of OMZ intensity and export production in the Eastern Tropical South Pacific (ETSP) developed in the present study and other selected records from the literature. A) $\delta^{15} \mathrm{~N}$ as a proxy for water column denitrification. B) Authigenic Re/Mo ratio ( $y$-axis inverted), the horizontal dashed line indicates the value of $0.4 \times 10^{-3}$ which corresponds to the ratio of the concentration of these metals in the sea-water (Crusius et al., 1996). C) Export production in the ETSP as indicated by the Nickel EF. The continuous lines indicates the December to February insolation at $15^{\circ} \mathrm{S}$ (Berger et al., 1978). D) Authigenic Rhenium concentrations from a sediment core off Chile (Muratli et al., 2010), where low values imply better-oxygenated sediments. E) Opal flux from a sediment core taken in the Southern Ocean (Anderson et al., 2009). F) Neodymium radiogenic isotope composition from a sediment core taken in front of Baja California (Basak et al., 2010); indicating water mass variations at the Baja California site: North Pacific Intermediate Water (NPIW) and Antarctic Intermediate Water (AAIW). The acronyms listed as in Figure 2. 